\title{
KAFKAS/DOĞU CEPHESİ'NDE TÜRK ORDUSUNUN İAŞE VE İKMAL DURUMU
}

Öz: Orduların muharebe kabiliyetini doğrudan etkileyen lojistik faktörlerin başında iaşe ve ikmal hizmetleri gelir. Zira bu hizmetler, yalnızca harp zamanlarında değil sükûnetin hâkim olduğu zamanlarda da kesintisiz olarak yürütülmesi gereken faaliyetlerdendir. Olağanüstü bir mücadelenin verildiği harp zamanlarında ise bu hizmetlerin önemi bir kat daha artar. Öyle ki muharebeler esnasinda askerlerin yaşadığı büyük enerji kaybının zamanında karşılanamaması orduyu bedensel ve ruhsal açıdan çöküntüye uğratır.

Çalışmada, Birinci Dünya Savaşı'nda Kafkas Cephesi'nin savunulmasını üstlenen 3'üncü Ordunun iaşe ve ikmal faaliyetleri ele alındı. Bu kapsamda iaşe maddelerinin temini, depolanması ve orduya ulaştırılması süreci incelenerek ordunun iaşe hususunda yaşadığı zorluklar ile

\section{Yavuz Selim ÇELOĞLU}

(Arş. Gör. Dr.)

https://orcid.org/0000-0002-7962-2982

ys_celoglu@hotmail.com

Bingöl Üniversitesi, Türkiye

Geliş Tarihi: 05.01.2021

Kabul Tarihi: 05.07.2021

Özgün Makale

DOI:10.46953/askeritarih.854676 bunların nedenleri ortaya konuldu. Böylece iaşe ve ikmal hizmetlerinin Türk ordusunun muharebe gücüne etkisi ve harbin gidişatı üzerindeki tesiri ortaya konulmaya çalışıldı. Çalışma, harbin başlangıcından 18 Aralık 1917 tarihli Erzincan Mütarekesi'nin imzalanmasına kadar geçen süre ile sınırlandırılmıştır.

Anahtar Kelimeler: Osmanlı Devleti, Birinci Dünya Savaşı, Kafkas Cephesi, Türk Ordusu, İaşe ve İkmal.

\section{FOOD AND SUPPLY STATUS OF TURKISH ARMY} IN CAUCASIAN/EASTERN FRONT

Abstract: Food and supply services are the leading logistical factors directly affecting combat capability of armies. This is because these services are not only among the most important activities that should be carried out without interruption in times of war, but also when peace prevails. The importance of these services is especially significant in times of war in which a violent struggle occurs. As a result, the inability to meet the great loss of energy consumed by the soldiers during war time causes the army to collapse both physically and spiritually.

This study examines the food and supply activities of the $3^{\text {rd }}$ Army which undertook the defense of the Caucasian Front in the First World War. The study also discusses the process of supply, storage and transportation of food materials to the army and reveals the causes of the difficulties the army faced regarding food supply. Thus, the study shows the effect of food and supply services on the combat power of the Turkish army and on the course of the war. The study has been limited to the period from the beginning of the war to the signing of the Armistice of Erzincan on 18 December 1917.

Keywords: Ottoman State, First World War, Caucasian Front, Turkish Army, Food and Supply. 


\section{Giriş}

27 Ekim 1914'te Alman Amiral Souchon komutasında Karadeniz'e çıkan Osmanlı donanması, 29 Ekim 1914 sabahında Rusların Sivastopol, Odessa, Novarosiski ve Kefe deniz üslerini bombardıman etmesiyle Rusya ile Osmanlı Devleti arasındaki harp fiilen başlamış oldu. Bunun üzerine Rus Kafkas Ordusu, 1 Kasım 1914'te Kötek, Musun, Narman ve Kaleboğazı mevkilerinden Türk topraklarına girmeye başladı. ${ }^{1}$

Rusların ilerleyişi, Kafkas Cephesi'ni korumakla görevli 3'üncü Ordu tarafindan Köprüköy ve Azap Savaşlarıyla durdurulsa da Sarıkamış Muharebelerinde ağır kayıplar veren 3'üncü Ordu, Ruslar karşısında tutunamayarak peyderpey geriye çekildi. Nitekim 16 Şubat 1916'da Erzurum'u işgal eden Ruslar, Şubat 1916'da Karadeniz kıyısı, Çoruh ve Murat Nehri doğrultusunda sürdürdükleri taarruzlar neticesinde Rize, İspir, Bitlis ve Muş'u işgal etti. 18 Nisan'da Trabzon'u işgal eden Rus ordusu yaz aylarında devam ettirdikleri taarruzlar neticesinde 19/20 Temmuz'da Bayburt'u 24 Temmuz'da ise Erzincan'1 ele geçirdi. Böylece Rus ordusu 1916 yılı Eylül'ünde Tirebolu-Kelkit-Erzincan-Kiğı-Muş-Van Gölü hattına kadar olan bölgeyi ele geçirdi. 6 Eylül 1916'da Rus ordusu bütün cephede taarruzlarını devam ettirmek istediyse de Türk ordusu tarafindan püskürtülmeleriyle cephede sükûnet başladı. ${ }^{2}$

1917 senesine gelindiğinde Rusya'da Bolşevik İhtilali'nin patlak vermesiyle Kafkas Cephesi'ndeki çarpışmalar durma noktasına geldi. Bolşevik Hükûmetini tanımayarak yeni bir idare kurmuş olan Kafkas Komiserliği ile 18 Aralık 1917'de yapılan Erzincan Mütarekesi ile yaklaşık 3 yıl 50 gün süren Osmanl1-Rus Savaşı fiilen ve resmen sona erdi. ${ }^{3}$

\section{Ordunun İaşe İhtiyacının Karşılanması}

Osmanlı Devleti, savaş esnasında askere verilmesi gereken günlük tayınat miktarını yasal olarak belirlemişti. Buna göre askere günde yaklaşık

\footnotetext{
${ }^{1}$ Akdes Nimet Kurat; Türkiye ve Rusya XVIII. Yüzyıl Sonundan Kurtuluş Savaşı'na Kadar Türk-Rus İlişkileri (1798-1919), TTK Yayınları, Ankara, 2011, s. 243-244. Birinci Dünya Harbi’nde Türk Harbi Kafkas Cephesi 3’üncü Ordu Harekâtı, C II Kitap I, Genelkurmay Basımevi, Ankara, 1993, s. 2. ${ }^{2}$ Türk Silahlı Kuvvetler Tarihi Osmanlı Devri Birinci Dünya Harbi İdari Faaliyetler ve Lojistik "X. Cilt"; Gnkur. Basımevi, Ankara, 1985, s. 314. Alman Yarbay Guze; Birinci Dünya Savaşı’nda Kafkas Cephesi'ndeki Muharebeler, çev. Yarbay Hakkı (Akoğuz), Yay. haz. Alev Keskin, Genelkurmay Askerî Tarih ve Stratejik Etüt Başkanlığı Yay., Ankara, 2007, s. 74. Mareşal Fevzi Çakmak; Birinci Dünya Savaşı'nda Doğu Cephesi, Genelkurmay Basımevi, Ankara, 2005, s. 306.

${ }^{3}$ Kurat; s. 334.
} 
üç bin kalorilik bir tayınatın verilmesi gerekiyordu. ${ }^{4}$ Dolayısıyla askerin günlük iaşe miktarı ile ordunun iaşe kuvveti ${ }^{5}$ göz önünde bulundurularak ordunun günlük iaşe ihtiyacı tespit edilirdi. Savaş esnasında 3'üncü Ordunun günlük iaşe kuvveti her an değişmekle birlikte, ordunun günlük iaşe ihtiyacı yaklaşık 200 ton civarındaydı. Ayrıca ordu bünyesinde bulunan hayvanların günlük yaklaşık 250-300 tonluk yem ihtiyacı da dâhil edildiğinde ordunun günlük iaşe ihtiyacı ortalama 450-500 tona tekabül ediyordu. ${ }^{6}$

Osmanlı Devleti, harp esnasında ordunun iaşe ihtiyacını karşılayabilmek amaciyla Alman iaşe sistemini örnek alarak ülke topraklarını iaşe bölgelerine ayırdı ve her orduya bir iaşe bölgesi tahsis etti. Böylece ordular; insan kaynağı başta olmak üzere iaşe, hayvan, nakliye araç gereçleri vb. her türlü lojistik ihtiyaçlarını öncelikle kendilerine tahsis edilen bu bölgelerden karşılamak durumundayd $1 .{ }^{7}$ Orduların iaşe sınırları, ordunun iaşe ihtiyacı ile bölgedeki kaynakların durumu göz önünde bulundurularak Başkumandanlık Vekâleti, Genelkurmay Başkanlığ (Erkânıharbiyeiumumiye Riyaseti) ve Menzil Genel Müfettişliğince belirlenirdi. Ancak orduların iaşe bölgeleri sabit olmayıp ordunun ihtiyaçları ve bölgedeki kaynakların durumu göz önünde bulundurularak orduların iaşe sınırlarında her an bir değişikliğe gidilebilirdi. ${ }^{8}$

Seferberliğin ilanından itibaren Erzurum, Trabzon, Mamuretülaziz, Diyarbekir, Van, Bitlis ve Musul vilayetleri ile Canik Mutasarrıflığını kapsayan oldukça geniş bir bölge, 3'üncü Ordunun iaşe bölgesi olarak

\footnotetext{
${ }^{4}$ Düstur; “Askerî Tayınât ve Kanûn-1 Muvakkatı”, Tertip II, C 6, s. 1286-1301.

${ }^{5}$ Orduların iaşe ihtiyacı belirlenirken yalnızca muharip asker sayısı değil gerek ordu harekât bölgesinde gerekse menzil mıntıkasında istihdam edilen tüm geri hizmet kıtaları ile depo talimgâhlarında bulunan ihtiyat askerleri, askerî hastanelerin ihtiyaçları ve jandarma taburlarının iaşe ihtiyaçları göz önünde bulunduruldu. Osmanlı askerî literatüründe iaşe edilmesi gereken bu genel mevcut, "ordunun iaşe kuvveti” olarak ifade edilirdi. Tuncay Öğün; Kafkas Cephesi'nin I. Dünya Savaşı'ndaki Lojistik Desteği, Dergâh Yay., İstanbul, 2015, s. 53.

6 3'üncü Ordunun harp başlangıcındaki iaşe kuvveti yaklaşık 200 bin insan ve 70 bin hayvan civarındaydı. MSB Arşiv ve Askerî Tarih Daire Başkanlığı Arşivi; BDH, Kls. 3055, Dos. H3, Fih. 3-19a. BDH; Kls. 74, Dos. 376, Fih. 1-81. BDH; Kls. 1131, Dos. 39, Fih. 1, 1-2, 1-2a; 11-3; 14-2; 14-3. Fevzi Çakmak; s. 305-306. Kur. Alb. Aziz Samih (İlter); Birinci Dünya Savaşı'nda Kafkas Cephesi Hatıraları, Genelkurmay Basımevi, Ankara, 2007, s. 29, 57. Hafız Hakkı Paşa; Hafız Hakkı Paşa'nın Sarıkamış Günlüğü, Yay. haz. Murat Bardakçı, Türkiye İş Bankası Kültür Yay., İstanbul, 2020, s. 58.

${ }^{7}$ Osmanlı Devleti Balkan Savaşları öncesinde Alman lojistik sistemini örnek alarak Menzil teşkilatı adı altında yeni bir lojistik sistem oluşturdu. Bu sistem Birinci Dünya Savaşı'nda da yürürlükte bulunuyordu. Yavuz Selim Çeloğlu; Çanakkale Cephesi’nde Askerî Nakliye Hizmetleri: 5. Ordu Menzil Teşkilatı, Yayımlanmamış Doktora Tezi, Elâzı̆̆, 2018, s. 4-5. Guze; s. 4.

${ }^{8}$ Çeloğlu; Çanakkale Cephesi'nde Askerî Nakliye Hizmetleri, s. 43.
} 
belirlendi. ${ }^{9}$ Kısa bir süre sonra Sivas vilayetinin de dâhil edilmesiyle ordunun iaşe bölgesi daha da genişletildi. ${ }^{10}$

Harita 1: 3'üncü Ordu İaşe Bölgesi

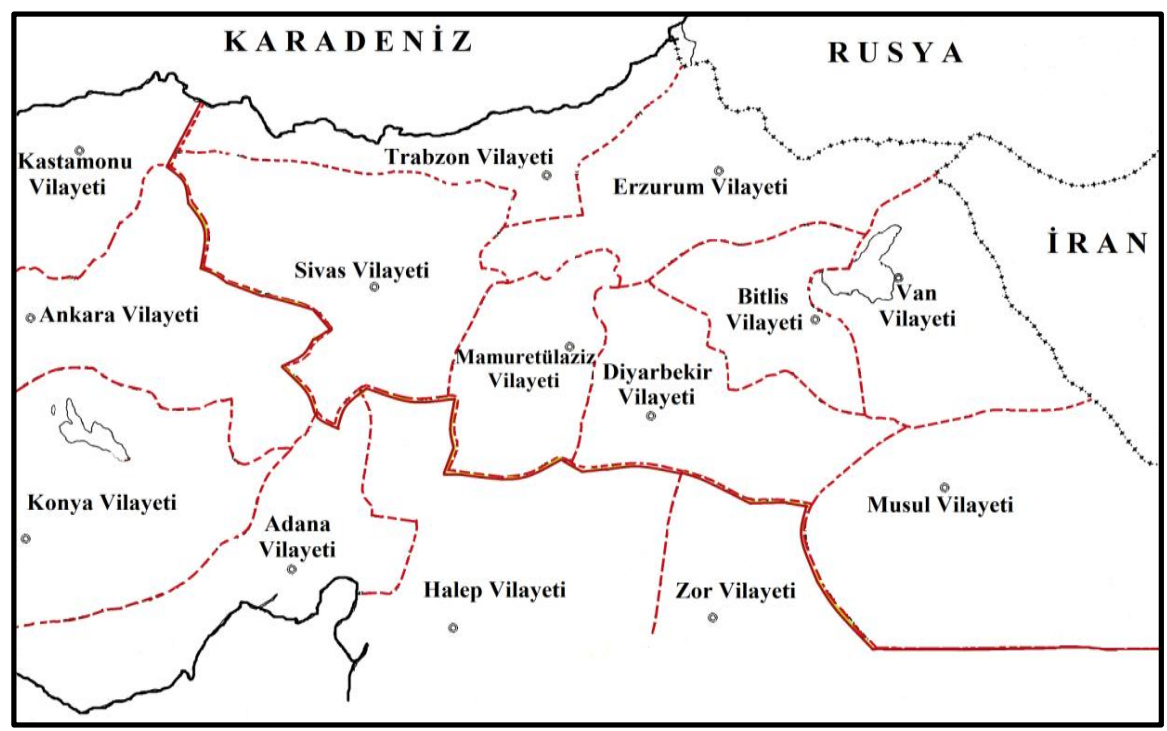

(Kaynak: BOA; HRT.h.140.)

Ordu iaşe bölgesinin büyük bölümünün Ruslar tarafından işgal edilmesi ve cephesinin savunulması amaciyla 2'nci Ordunun bölgeye intikal ettirilmesiyle 3'üncü Ordu iaşe bölgesi büyük oranda değişti. 1916 yıl1 Mayıs'ında yapılan değişiklikle Erzurum, Sivas, Trabzon vilayetleri ile Canik sancağ 3 'üncü Ordu iaşe bölgesine bırakılırken Bitlis, Diyarbekir ve Mamüratülaziz vilayetleri ile Urfa sancağı ve Behisni kazası 2'nci Ordu iaşe bölgesine dâhil edildi. Ayrıca Halep, Suriye, Beyrut ve Adana vilayetleri ile İçel, Maraş ve Kudüs sancakları 4'üncü Ordu iaşe bölgesi olarak belirlenirken Musul, Bağdat ve Zor vilayetleri ise 6'ncı Ordu iaşe bölgesine dâhil edildi. Daha önce 3'üncü Ordu iaşe sınırları içinde yer alan Bitlis, Diyarbekir ve Mamüratülaziz vilayetlerinin 2'nci Orduya ve Musul vilayetinin ise 6'ncı Ordu iaşe bölgesine dâhil edilmesiyle 3'üncü Ordu iaşe bölgesinin sınırları oldukça daraltılmış oldu. ${ }^{11}$

1916 yılı başından itibaren Rus ordusunun ileri harekâtı neticesinde Erzincan'a kadar olan oldukça geniş bir bölgenin işgal edilmesiyle 3'üncü Ordunun iaşe bölgesi yeniden tertiplendi. Buna göre ordunun lojistik

\footnotetext{
${ }^{9}$ BDH; Kls. 3055, Dos. H1, Fih. 1-1a, 1-10a.

${ }^{10}$ BDH; Kls. 1129, Dos. 29, Fih. 7. BDH; Kls. 3055, Dos. H4, Fih. 2-14a. BOA; DH. İ. UM., 82/1-17. Guze; s. 4. Öğün; s. 47.

${ }^{11}$ BDH; Kls. 74, Dos. 376, Fih. 1-32. BDH; Kls. 74, Dos. 376, Fih. 1-32. Guze; s. 88.
} 
merkezi Suşehri'ne taşındı. İaşe sınırları ise Giresun-Erzincan hattının batısından başlayarak Ayancık (Sinop), Boyabat, Osmancık, İskilip, Sungurlu, Çorum, Yozgat, Mucur, Avanos, Niğde ve Ulukışla'yı kapsayacak şekilde yeniden tertiplendi. Böylece 3'üncü Ordu iaşe bölgesi batıda 1'inci Ordu iaşe bölgesiyle güneyde ise 2'nci ve 4'üncü Ordu iaşe bölgesiyle sınırdaş oldu. ${ }^{12} \mathrm{Bu}$ tarihten itibaren Ruslarla imzalanan mütarekeye değin 3'üncü Ordunun mevcut iaşe bölgesinde büyük bir değişlik yapılmadı. Ancak Bolşevik İhtilali sonrasında Rusya'nın Türk topraklarından çekilmesiyle başlayan Türk ileri harekâtı neticesinde daha önce kaybedilen toprakların ele geçirilmesiyle 3'üncü Ordunun iaşe bölgesi de bütünüyle değişti. ${ }^{13}$

Harita 2: 3'üncü Ordu İaşe Bölgesi

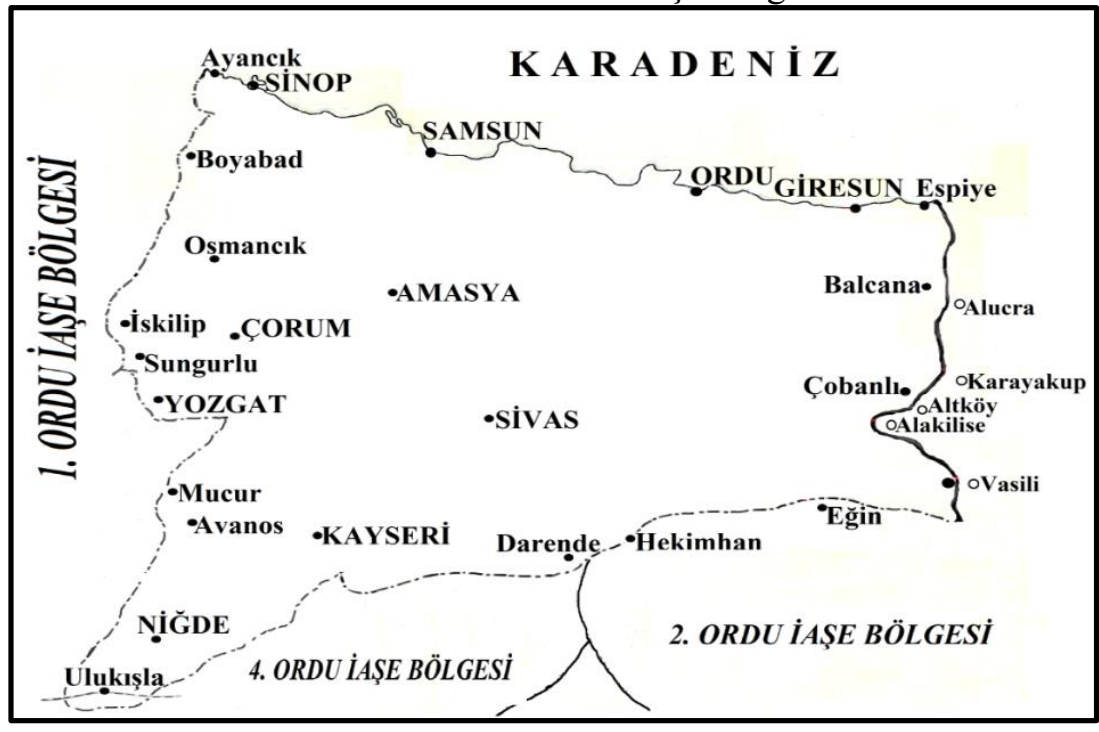

(Kaynak: MSB Arşiv ve Askerî Tarih Daire Başkanlığı Arşivi; Birinci

Dünya Harbi Koleksiyonu (BDH), Kls. 1139, Dos. 74, Fih. 11.)

Anadolu'nun genelinde olduğu gibi 3'üncü Ordu iaşe bölgesinde üretimin büyük bölümü buğday ve arpa başta olmak üzere mısır, yulaf, çavdar ve pirinçten oluşuyordu. 3'üncü Ordu iaşe bölgesi içinde yer alan Trabzon vilayetinde daha çok mısır ve pirinç ekilirken iç kesimlerde ise çoğunlukla arpa ve buğday ekilirdi. Bununla birlikte fasulye, nohut, mercimek, patates ve soğan bölgede en çok yetiştirilen ürünler arasındaydı. Bölgede yetişen bu ürünlerin önemli bir bölümü ayni olarak emaneten veya

\footnotetext{
${ }^{12}$ BOA; DH. İ. UM., 34/62. BOA; DH. ŞFR. 68/40. BOA; DH. ŞFR. 68/54. BDH; Kls. 1131, Dos. 39, Fih. 14-2. BDH; Kls. 1139, Dos. 74, Fih. 11. BDH; Kls. 1138, Dos. 69, Fih. 1-37, 1-53, 1-69. Çakmak; s. 306.

${ }^{13}$ BOA; DH. İ. UM, 82/1. BOA; DH. İ. UM., 20/2. BOA; DH. ŞFR. 87/347. Öğün; s. 168.
} 
mültezimlerce toplanan aşar vergisiyle karşıland. ${ }^{14}$ Hasat mevsiminde üreticinin elinde bulanan mahsulün $1 / 8$ 'i $(\% 12,5)$ alınarak vilayet ve sancak merkezinde bulunan aşar ambarlarında depolanırdı. Aşar vergisi olarak alınan bu ürünlerin bir bölümü doğrudan ordu iaşesi için ayrılırken bir bölümü de nakde çevrilerek gelir kalemi olarak hazineye aktarılırdı. Seferberliğin ilanıyla birlikte ordunun artan ihtiyaçlarını karşılayabilmek amaciyla ayni olarak toplanan ürünlerin nakde çevrilmesi usulüne son verildi. Dolayısıyla aşar vergisi olarak toplanan ürünlerin büyük bölümü ordunun iaşesini için harcand1. ${ }^{15}$

Orduların iaşe ihtiyacının yalnızca aşar vergisiyle karşılanması mümkün değildi. Bu durumda öteden beri savaş zamanlarında uygulamaya konan "Tekâlif-i Harbiye" usulüne başvuruldu. Bu amaçla 27 Temmuz 1914 tarihli Tekâlif-i Harbiye Kanunu yürürlüğe konuldu. Bu kanuna istinaden her vilayet ve sancakta, Tekâlif-i Harbiye Komisyonları teşkil edildi. $\mathrm{Bu}$ komisyonlar, halkın elinde bulunan ihtiyaç fazlası ürünlerin bedelinin $1 / 5$ 'ini peşin, kalan kısmını ise harbin bitimini takip edecek yılın bütçesinden ödemek şartıyla piyasadaki ürünlere el koymaya başladı. ${ }^{16}$ Ancak mal sahiplerine ürün bedelinin yalnızca $1 / 5$ 'inin peşin ödenmesi, komisyonlarca belirlenen ürün bedellerinin piyasanın çok altında olması ve uygulamada yaşanan aksaklıklar üreticiyi yalnızca kendisine yetecek kadar üretim yapmaya itti. Bu durum harp dolayısıyla azalmış olan ülke üretiminin daha da azalmasına ve ülkedeki iaşe buhranının daha da derinleşmesine neden oldu. Bunun üzerine 1 Mayıs 1916 tarihinde Tekâlif-i Harbiye usulünde değişikliğe gidilerek ürün bedelinin tamamı mal sahiplerine peşin olarak verilmeye başland $1{ }^{17}$ Buna rağmen halkın, Tekâlif-i Harbiye usulüne olan olumsuz bakışı değişmemiş ve bu yolla yapılan satın almalar her geçen gün daha da azalmıştır. ${ }^{18}$

Piyasadaki ürünlerin satın alınmasının bir diğer yolu da müteahhitler yoluyla yapılan satın almalardır. Genellikle Tekâlif-i Harbiye suretiyle temin edilemeyen bulgur, pirinç, sade (tereyağı), soğan, kuru fasulye, nohut, patates, kuru üzüm, şeker ve et gibi gıda maddeleri ile arpa, fiğ ve küşne gibi

\footnotetext{
${ }^{14}$ Osmanlılarda başlangıçtan XIX. yüzyılın ortalarına kadar aşar (öşür) vergisi "iltizam” usulüyle yani özel teşebbüs gibi hareket eden mültezimlerce toplamıștır. Ancak Tanzimat'ın İlanı'yla birlikte bu vergi daha çok devletin maaşlı memurları eliyle yani "emaneten" toplanılmaya başlanmışsa da devletin sonuna değin, her iki metotla da aşar vergisi toplanılmaya devam edilmiştir. Geniş bilgi için bk. Mehmet Genç; "İltizam", İA, C 22, s. 154.

${ }^{15}$ BOA; DH. İ. UM., 82/1. BOA; DH. İ. UM, 4-2/5-26. BOA; MV. 197/108. Guze; s. 3.

${ }^{16} 14$ Temmuz 1330 tarihli “Tekâlif-i Harbiye'nin Suret-i Tarhı Hakkında Kanun” için bk. Düstur; Tertip II, C 6, s. 1011.

${ }^{17}$ Düstur; "Tekâlif-i Harbiye'nin Suret-i Tarhına Mütedair 4 Ramazan 1332 Tarihli Kanun’a Müzeyyel Kanun-1 Muvakkat" Tertip II, C 8, s. 938.

${ }^{18}$ Halkın şikâyet ettiği hususların başında idari makamların bazı keyfi uygulamaları ve "tekâlifi harbiye" adı altında yapılan müsadere uygulamaları geliyordu. Vedat Eldem; Harp ve Mütareke Yıllarında Osmanlı İmparatorluğu'nun Ekonomisi, TTK Yay., Ankara, 1994, s. 36.
} 
hayvan yemleri müteahhitler vasitasıyla piyasadan satın alınarak orduya aktarılırd $1{ }^{19}$ Bununla birlikte az da olsa iane (yardım) suretiyle de ordunun bazı ihtiyaçları karşılandı. Özellikle hayvan yemi olarak kullanılan saman, iane suretiyle karşılanmaya çalışıldd. ${ }^{20}$

Orduların ihtiyaçlarını yalnızca kendi iaşe bölgelerinden karşılayabilmeleri elbette mümkün değildi. $\mathrm{Bu}$ durumda Levazımat-1 Umumiye Dairesi ve Menzil Genel Müfettişliği vasıtasıyla yurt içinden veya yurt dişından karşılanmaya çalışıldı. Nitekim 3'üncü Ordunun iaşe ihtiyacının yaklaşık 1/4'ü kendi iaşe bölgesi dışından yani merkezden gönderilen iaşe maddeleri ile karşılandi. ${ }^{21}$

\section{Depolama ve Nakliye Hizmetlerinin Yürütülmesi}

Osmanlı Devleti, sefer esnasında ordunun lojistik ihtiyaçlarını karşılayabilmek amacıyla Balkan Savaşları öncesinde yeni bir geri hizmet sistemi oluşturmaya başladı. Alman sistemi örnek alınarak oluşturulmaya çalışlan bu yeni lojistik sisteme göre sefer esnasında orduların lojistik faaliyetleri; ordu harekât bölgesi, menzil mıntıkası ve yurt içi (ana vatan) bölgesi olmak üzere üç ayrı bölgede yürütülecekti. Dolayısıyla iaşe maddelerinin temini, depolanma ve nakliye hizmetleri de üç ayrı bölgede ve üç ayrı idari otorite tarafindan gerçekleştirilecekti. ${ }^{22}$

\section{a. Ordu Harekât Bölgesinde Depolama ve Nakliye Hizmetlerinin Yürütülmesi}

Yurt içinden veya menzil bölgesinde temin edilen iaşe maddeleri kademe kademe ileri taşınarak ordu harekât bölgesinin hemen gerisinde tesis edilen menzil sahra ambarlarına ulaştırılırdı. Ordu harekât bölgesi içinde yer alan kolordu veya firkalar ise kendilerine ait nakliye kolları ile ihtiyaçlarını bu ambarlardan alarak kolordu veya firkaların gerilerinde tesis edilen sahra veya tevzi ambarlarına (dağıtım merkezleri) ulaştırırdı. ${ }^{23}$

Başlangıçta 3'üncü Ordu harekât bölgesi Erzurum'un doğusunda yer alan İspir, Hınıs, Tutak, Erciş, Van, Başkale ve Şemdinan (Şemdinli) hattının

\footnotetext{
${ }^{19}$ BOA; M.V., 197/108. BOA; DH. İ. UM, 4-2/5-26. BDH; Kls. 3055, Dos. H3, Fih. 3-20, 3-20a. BDH; Kls. 3055, Dos. H2, Fih. 2.

${ }^{20}$ BOA; M.V., 197/108.

${ }^{21}$ BOA; DH. ŞFR., 56/97. Kuvvei Umumiyeler Hakkında Talimat; Matbaa-i Askeriye, İstanbul, 1333, s. 4. Çakmak; s. 309.

${ }^{22}$ Geniş bilgi için bk. Yavuz Selim Çeloğlu; Çanakkale Cephesi'nde Askerî Nakliye Hizmetleri, s. 17-22. Bülent Durgun; Balkan Harbi'nde Osmanlı Ordusunun Ulaştırma Faaliyetleri 1912-1913, İstanbul, 2018, s. 117.

${ }^{23}$ Harp esnasında sahra ambarlarının tesis edilmesine imkân bulunmadığı zamanlarda kolordu veya firka başına birer tevzi ambarı kurulurdu. Kolorduların levazım reisi iaşe hususunu düzenlerdi. Menzil Hidemât-1 Nizamnamesi; Matbaa-i Askeriye, Süleymaniye, 1327, s. 56, madde 55.
} 
doğusunda kalan bölge, ordu harekât bölgesi sınırları içinde bulunuyordu. ${ }^{24}$ Ordunun peyderpey geriye çekilmesiyle ordu harekât bölgesinin geri hatt1 Karagöbek-Hasankale-Mescitli-Ketvan hattına alındı. Dolayısıyla 11'inci Kolordu iaşe ihtiyaçlarını Köprüköy'de kurulan sahra ambarından karşılamaya başladı. Köprüköy sahra ambarı ise ihtiyaçlarını Hasankale'de tesis edilen menzil sahra ambarından karşıllyordu. 10'uncu Kolordu için ise İd (Narman) ve Tortum'da birer sahra ambarı açıldı. Bu ambarlar da ihtiyaçlarını Karagöbek'te bulunan menzil sahra ambarından temin ediyordu. ${ }^{25}$

Ordunun sürekli geri çekilmesiyle ordu harekât bölgesinde bulunan sahra ambarlarının bulundukları mevkiler de sürekli değişti. Nitekim ordunun Bayburt hattına çekilmesiyle ordu ihtiyaçlarını Ardasa, Bayburt, Sansa ve Fem ambarlarından karşılamaya başladı. ${ }^{26}$ Ancak 3 'üncü Ordunun Ruslar tarafından Erzincan hattına atılmasıyla ordu harekât mıntıkasının geri hattında yer alan Alucra, Karayakub, Altköy, Alakilise ve Vasili'de birer ordu sahra ambarları oluşturuldu. $\mathrm{Bu}$ ambarlar ise ihtiyaçlarını daha gerilerde bulunan Balcina, Ağvanıs, Gemecik ve Nezgeb menzil ambarlarından karşılıyordu. ${ }^{27}$

\section{b. Menzil Bölgesinde Depolama ve Nakliye Hizmetlerinin Yürütülmesi}

Birinci Dünya Savaşı'nda yürütülmekte olan geri hizmet sistemine göre ordu harekât bölgesinin gerisindeki belirli bir bölge Ordu Menzil Müfettişliklerinin hizmet sahası olarak belirlenirdi. Menzil Müfettişlikleri bağlı oldukları orduların iaşe ihtiyacını karşılayabilmek amacıyla sivil makamlarla iş birliği yaparak kendilerine tahsis edilen sınırlar içinde iaşe maddelerinin temin edilmesi ve bunların depolanarak orduya ulaştırılmasından sorumluydu. Gerek menzil bölgesinden toplanan gerekse yurt içinden temin edilen iaşe maddeleri menzil hatları üzerinde tesis edilen menzil ambarlarına depolanır ve buradan da menzile nakliye kolları vasıtasıyla peyderpey ileriye taşınarak ordu harekât alanın hemen gerisinde tesis edilen menzil sahra ambarlarına ulaştırılırdı. ${ }^{28}$

Menzil sınırları içinde, ordu adına temin edilen iaşe maddeleri, köylüden alınarak vilayet ve sancak merkezlerinde bulunan ambarlara nakledilirdi. Mülki idarenin denetimi altında bulunan aşar ve Tekâlifi

\footnotetext{
${ }^{24}$ BDH; Kls. 3055, Dos. H1, Fih. 1-10a.

${ }^{25}$ BDH; Kls. 3055, Dos. H7, Fih. 2-32, 2-32a. BDH; Kls. 3055, Dos. H11, Fih. 1-6a. BDH; Kls. 3055, Dos. H8, Fih. 3.

${ }^{26}$ BDH; Kls. 1131, Dos. 39, Fih. 1-3.

${ }^{27}$ BDH; Kls. 1138, Dos. 69, Fih. 1-37, 1-57, 1-65, 1-67.

${ }^{28}$ Menzil Hidemât-1 Nizamnamesi; Matbaa-i Askeriye, Süleymaniye, 1327, s. 3. Menzil Müessesâtı Hakkında Tarifat; Matbaa-i Askeriye, İstanbul, 1332, s. 2. BDH; Kls. 3055, Dos. H1, Fih. 1-9.
} 
Harbiye ambarlarında toplanan bu iaşe maddeleri, umumi nakliyatın kolayca yapılabileceği ana ikmal yolları üzerinde tesis edilen "müddehiri umumiye" veya "müddehir" adı verilen ambarlara aktarılırdı. Bu ambarlarda toplanan iaşe maddeleri ise menzil hatları üzerinde tesis edilen aktarma ambarlarına nakledilir ve bu ambarlardan da peyderpey ordu harekât bölgesinin gerisinde yer alan Erzurum Müddehiri Umumiye Ambarına ulaştırılırdı. Nitekim Trabzon-Ardasa-Gümüşhane-Bayburt-Aşkale ve Erzurum menzil hatt1 üzerinde Trabzon ve Bayburt'ta müddehir ambarı tesis edildi. Ayrıca bu hat üzerinde Maçka, Hamsiköy, Gümüşhane ve Aşkale'de aktarma ambarları tesis edilmişti. Böylece gerek Trabzon vilayetinden gerekse merkezden deniz yoluyla Trabzon'a ulaştırılan iaşe maddeleri Trabzon Müddehiri Umumiye Ambarında toplanır ve buradan da söz konusu menzil hattı üzerinden Erzurum'a ulaştırılırd.

Sivas-Koçhisar-Zara-Andaras-Refahiye-Erzincan-Mamahatun ve Erzurum menzil hattı üzerinde ise Erzincan'da Müddehiri Umumiye Ambarı, Sivas ve Mamahatun'da ise birer müddehir ambarı tesis edildi. DiyarbekirMamuretülaziz-Keban-Eğin ve Kemah üzerinden Erzincan'a ulaşan menzil hattı üzerinde Eğin'de aktarma ambarı, ayrıca Diyarbekir ve Mamuretülaziz vilayetlerinden Palu ve Kiğı hattı ile Erzurum'a ulaşan yol güzergâhı üzerinde de Palu ve Kiğı'da birer aktarma ambarı tesis edildi. Sivas, Diyarbekir ve Elâzı ğ vilayet ambarlarından toplanan iaşe maddeleri Erzincan Müddehiri Umumi ambarına aktarılır ve buradan da peyderpey Erzurum'a ulaştırılırdı. Diyarbekir ve Mamuretülaziz vilayetlerinden toplanan iaşe maddelerinin bir kısmı ise Palu ve Kiğı aktarma ambarları üzerinden Erzurum'a nakledilirdi.

Cizre-Siirt-Bitlis-Ahlat-Bulanık-Hınıs ve Mescitli menzil hatt1 üzerinde ise Bitlis'te Müddehir-i Umumiye ambarı, Bulanık ve Ahlat'ta birer müddehir ambarı, Cizre, Ahlat, Hınıs ve Mescitli'de birer aktarma ambarı tesis edildi. Böylece Van vilayeti, Ahlat ve Tatvan ambarlarından gönderilen iaşe maddeleri Bulanık Müddehiri Umumi Ambarında, Musul vilayeti, Bitlis vilayeti ve Van vilayetinin Bitlis'e yakın bölgelerinden temin edilen iaşe maddeleri ise Bitlis Müddehiri Umumi ambarında toplanır ve buradan da söz konusu menzil hattı üzerinden Hınıs, Mescitli ve Erzurum'daki ambarlara ulaştırılırdı. ${ }^{29}$

Menzil Müfettişliğinin sınırları başlangıçta ordu iaşe bölgesinin büyük bölümünü kapsayacak şekilde geniş tutulmuşken menzil teşkilatının özellikle nakliye hususunda yaşadığı sorunlar nedeniyle Menzil Müfettişliğinin

\footnotetext{
${ }^{29}$ BDH; Kls. 3055, Dos. H1, Fih. 1-10a. BDH; Kls. 3055, Dos. H4, Fih. 2-2a, 2-3. BDH; Kls. 3055, Dos. H10, Fih. 5-53. BDH; Kls. 3055, Dos. H4, Fih. 2-3. BDH; Kls. 3055, Dos. H2, Fih. 2-7, 2-7a. BDH; Kls. 3055, Dos. H1, Fih. 1-11.
} 
sinırları daraltıldı. Böylece Karagöbek-Hasankale-Mescitli ve Hınıs hatt1 menzil ileri hattı olarak belirlenirken Bayburt-Tercan-Kiğı hattı ise menzilin geri hattını oluşturdu.

Harita 3: 3'üncü Ordu Menzil Mintıka Hududu

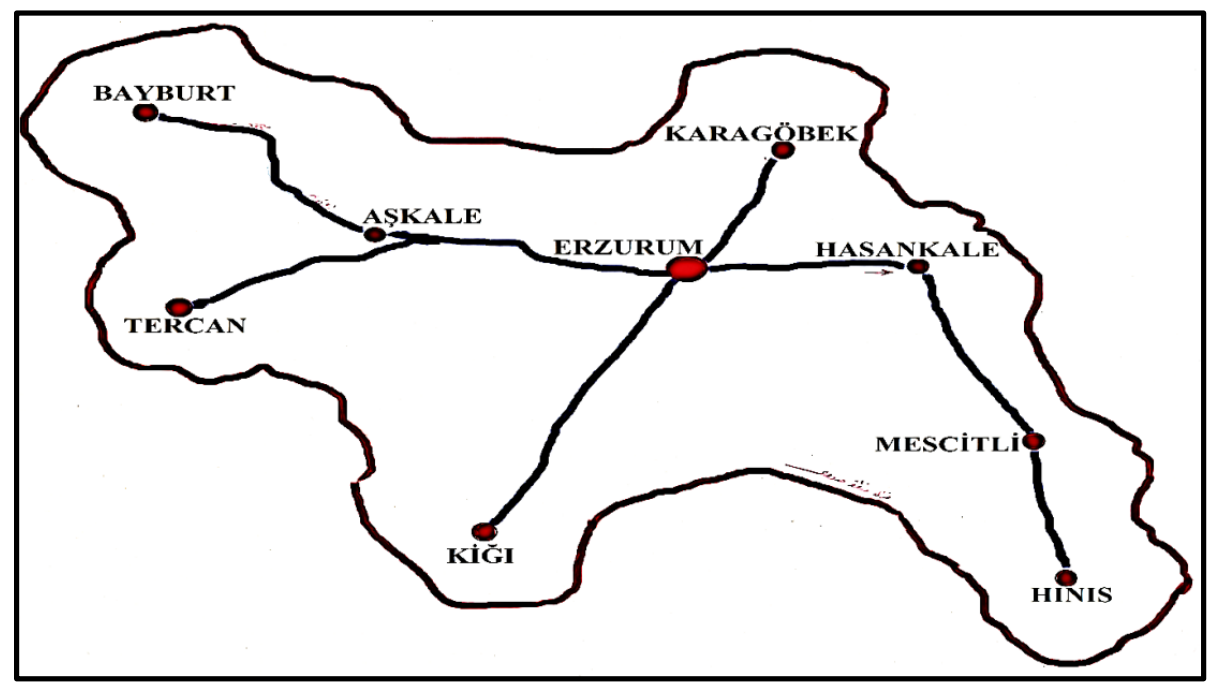

(Kaynak: BDH; Kls. 1129, Dos.29, Fih. 10-2.)

3’üncü Menzil Müfettişliğinin sınırlarının daraltılmasıyla ordu iaşe bölgesi de ikiye ayrıldı. Mescitli, Ketvan, Hasankale, Deliler, Karagöbek ve Kaspirik hattı (dâhil) ile Erzurum, İspir, Bayburt, Tercan, Kiğı, Hınıs ve Hasankale'nin kaza hududunu (dâhil) kapsayan bölge Birinci İaşe Bölgesi olarak belirlendi. Birinci İaşe Bölgesi’nden başlayarak Trabzon, Samsun, Sivas, Gümüşhane, Erzincan, Eğin, Mamuretülaziz, Palu, Siirt, Muş, Bulanık ve Ahlat hududunu (dâhil) içine alan bölge ise İkinci İaşe Bölgesi olarak belirlendi. ${ }^{30} \mathrm{Bu}$ düzenleme ile Birinci İaşe Bölgesi'ndeki ikmal faaliyetleri menzil müfettişliğine ait nakliye kolları vasıtasıyla gerçekleştirilirdi. İkinci İaşe Bölgesi'ndeki ikmal hizmetleri ise yerel yönetimlere bırakıldı. Dolayısıyla İkinci İaşe Bölgesi'nde temin edilen iaşe maddeleri vilayetlere ait nakliye kollarıyla Birinci İaşe Bölgesi geri hattını oluşturan Bayburt,

\footnotetext{
${ }^{30}$ Birinci İaşe Bölgesi, menzil bölgesinin sınırlarını kapsarken İkinci İaşe Bölgesi de yurt içi (dâhilî memleket) sınırlarını kapsıyordu. Erzurum'u içine alan yaklaşık 150 kilometrelik bölge Birinci İaşe Bölgesi olarak belirlenmiști. Birinci İaşe Bölgesi geri hattından başlayarak tüm 3'üncü Ordu iaşe sınırlarını kapsayan bölge ise İkinci İaşe Bölgesi olarak belirlendi. Bk. Harita 4. BDH; Kls. 3055, Dos. H10, Fih. 5-21a, 22. BDH; Kls. 3055, Dos. H11, Fih. 1-32. BDH; Kls. 3055, Dos. H1, Fih. 1-1a. BDH; Kls. 3055, Dos. H11, Fih. 1-6, 1-7, 1-8a. BDH; Kls. 3055, Dos. H11, Fih. 1-32. BOA; DH. ŞFR. 50/4.
} 
Erzincan, Kiğı ve Hınıs ambarlarına nakledilir ve bu ambarlardan da menzile ait nakliye kolları ile ordu harekât bölgesine ulaştırılırd. ${ }^{31}$

Kroki 1: Birinci ve İkinci İaşe Bölgesi

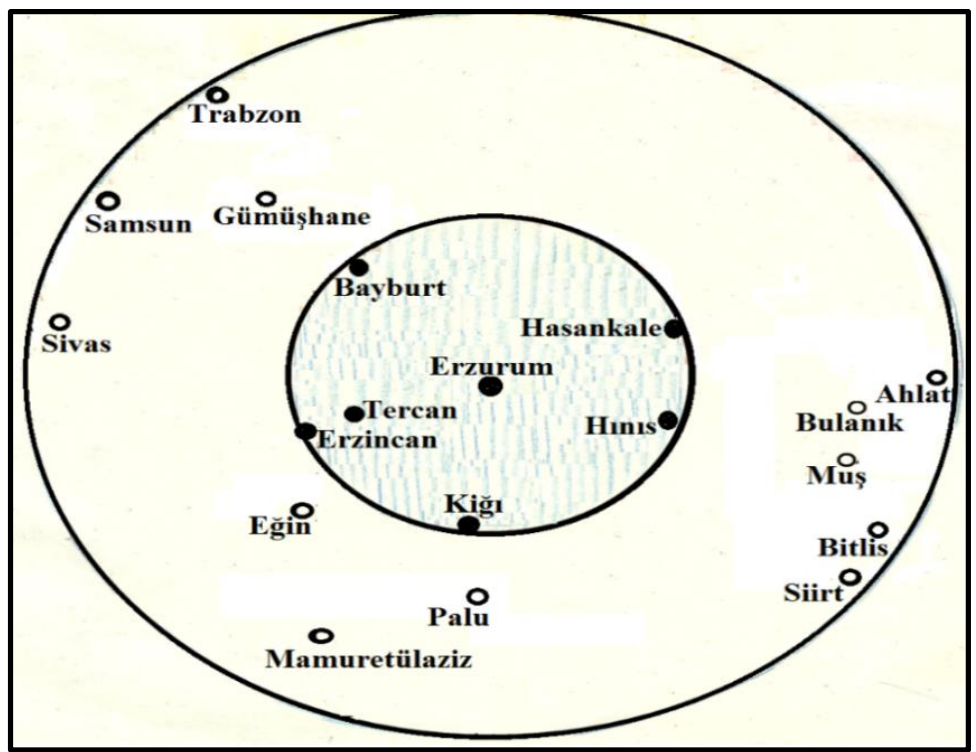

(Kaynak: BDH; Kls. 3055, Dos. H11, Fih. 1-32.)

Menzil sinırlarının daraltılmasıyla Trabzon-Erzurum kara yolunun Bayburt-Erzurum bölümü, Erzincan-Erzurum kara yolunun Tercan-Erzurum bölümü, Elâziz-Palu-Kiğı-Erzurum yolunun Kiğı-Erzurum bölümü ile BitlisMuş-Gümgüm-Hınıs-Hasankale (Pasinler) yolunun Hınıs-Hasankale bölümü Birinci İaşe Mıntıkası sınırları içinde kaldı. Menzil bölgesinden toplanan veya yurt içinden menzil bölgesine sevk edilen iaşe maddeleri bu yollar üzerinde tesis edilen menzil ambarlarına ve buradan da peyderpey Erzurum'da bulunan ana ikmal merkezine ulaştırılırdı. Nitekim TrabzonErzurum yolunun Bayburt, Kophanları ve Aşkale'de birer menzil ambarı tesis edildiği gibi Madenhanları-Pırnakapan-Evreni ve Ilıca'da da birer ihtiyat ambarı tesis edilmişti. Tercan-Erzurum yolu üzerinde Tercan'da bir menzil ambarı ve Yeniköy'de de bir ihtiyat ambarı tesis edilmişti. KiğıErzurum yolu üzerinde ise Kiğı'da bir ihtiyat ambarı, Hakistun ve Melikan'da da birer menzil ambarı tesis edilmişti. Hınıs-Hasankale yolu üzerinde Hınıs-Söylemez ve Hasankale'de menzil ambarları ve Mescitli'de ise bir ihtiyat ambarı tesis edilmişti. Böylece Bayburt, Erzincan, Kiğı menzil

${ }^{31}$ BOA.; DH. ŞFR. 50/40.

Askerî Tarih Araştırmaları Dergisi (ATAD), Yıl 2021, Sayı 33:63-92 
hatları üzerinden Erzurum menzil ana ikmal deposuna sevk edilen iaşe maddeleri ordu harekât bölgesinin gerilerinde yer alan Hins (Aydınl1), Karagöbek, Korucuk, Hasankale, Mescitli ve Ketvan menzil sahra ambarlarına ulaştırılırdı. ${ }^{32}$

Menzil bölgesindeki nakliye hizmetleri ise menzile ait nakliye kolları ile gerçekleştirilirdi. Menzil sınırları içinde demir yolu hattı bulunmadığından nakliye hizmetleri büyük oranda at, öküz, deve, merkep gibi yük hayvanlarından oluşan nakliye kolları ile gerçekleştirilirdi. ${ }^{33}$ Nakliye hizmetinde kullanılan bu yük hayvanları başlangıçta mübayaa (satın alma) yoluyla temin edilmeye çalışıldı. Ancak bunun yeterli olmadığının anlaşılmasıyla harp yükümlülüğü çerçevesinde Menzil Müfettişliklerinin illerdeki temsilcilikler aracılığıyla halkın elindeki ordu hizmetine elverişli nakliye araçlarına el konulmaya başland1. ${ }^{34}$ Bunun için 3'üncü Menzil Müfettişliği bünyesinde "Vesait-i Nakliye Komisyonları" kurularak halkın elinde bulunan her türlü yük hayvanı ve nakliye aracına el konuldu. ${ }^{35}$

Başlangıçta menzil bölgesindeki nakliye hizmetleri oldukça yetersizdi. Ancak Ahmet Avni Paşa'nın Menzil müfettişliğini devralmasıyla nakliye hususunda yeni düzenlemeler yapıldı. Bunun için ilk olarak menzil bölgesinde istihdam edilen nakliye kollarının sayısı tespit edilerek nakliye kolları yeniden numaralandırıldı. Ayıca nakliye kollarının görev yapacağı menzil hatları da yeniden tertiplendiği gibi nakliye kollarındaki hayvan ve araç sayısı arttırılarak her bir nakliye kolunun yük taşıma kapasitesi 10 tona çıkarıldı. Nakliye hizmetlerinin bir düzen içinde yürütülebilmesi için hareket cetvelleri hazırlanarak ikmal hizmetleri bu cetvellere göre yapılmaya başlandı. Ayrıca aynı hat üzerinde görev yapan nakliye kolları bir araya getirilerek nakliye taburları oluşturulmaya başlandı. Böylece her mıntıkadaki nakliye hizmetleri nakliye tabur kumandanı uhdesinde gerçekleştirilerek nakliye hizmetleri daha düzenli yürütülmeye başland $1 .{ }^{36}$ Nitekim Bayburt-

\footnotetext{
${ }^{32}$ BDH; Kls. 1129, Dos. 29, Fih. 10-2, 11-3; MSB; BDH; Kls. 3055, Dos. 14, Fih. 5-15, 5-22; BDH; Kls. 3055, Dos. H11, Fih. 1-6a, 1-7; BDH; Kls. 3055, Dos. H13 Fih. 4-8; BDH; Kls. 3055, Dos. H12, Fih.3-1.

${ }^{33}$ Hayvanların yük taşıma kapasiteleri hayvanların cinslerine göre belirlenmiştir. Buna göre bir merkeple $50 \mathrm{~kg}$, bir mekkâreyle $80 \mathrm{~kg}$, bir deveyle $150 \mathrm{~kg}$ yük taşınabilirdi. Ayrıca tek atlı araba ile $200 \mathrm{~kg}$, çift atlı araba $400 \mathrm{~kg}$, bir manda arabası $500 \mathrm{~kg}$, bir kağnı arabası $150 \mathrm{~kg}$, bir öküz arabası $400 \mathrm{~kg}$ ve dört bargirli arabalar ile de $1.000 \mathrm{~kg}$ yük bir defa da taşınabilirdi. Kafkas Cephesi 3'üncü Ordu Harekâtı; s. 55. Yavuz Selim Çeloğlu; Çanakkale Cephesi'nde 5. Ordunun İaşesi, Yayımlanmamış Yüksek Lisans Tezi, Elâzı̆̆g, 2013, s. 95.

${ }^{34}$ Birinci Dünya Harbi İdari Faaliyetler ve Lojistik X. Cilt; s. 217. BDH; Kls. 1131, Dos. 39, Fih. 1-4.

35 3'üncü Menzil Müfettişliği halkın elinde bulunan nakliye araçlarını toplamak amaciyla Menzil Sertabibi Ali Rıza Bey başkanlığında Seyyar Jandarma Kumandanı Mehmet Bey, İnzibat Zabiti Yüzbaşı Nuri Efendi, Menzil Karargâh Baytarı Ömer Lütfi Efendi ve Menzil İaşe Memuru Fehmi Efendi'den oluşan "Menzil Vesaiti Nakliye Komisyonu” teşkil etti. BDH; Kls. 3055, Dos. H3, Fih. 3-17.

${ }^{36}$ İlk olarak Binbaşı Şevket Bey uhdesinde Birinci Menzil Nakliye Taburu teşkil edildi. Karabıyık-Tercan hattında istihdam edilen bu nakliye taburu, 1, 2, 3, 4, 5, 6, 7, 8, 9, 10, 11. ve 12. develi nakliye kolundan
} 
Erzurum, Tercan-Erzurum, Kiğg-Erzurum, Hınıs-Hasankale, ErzurumKaragöbek ve Erzurum-Hasankale menzil hatları üzerinde çeşitli nakliye kolları görevlendirilmişti. Menzil bölgesinde nakliye kol sayılarının artmasıyla her menzil hattı üzerinde bir nakliye taburu teşkil edildi. Böylece her nakliye taburuna bir hat belirlenmiş ve bu hat üzerindeki nakliye hizmetleri bu taburların uhdesinde gerçekleştirilmeye başlandı. Nitekim Erzurum'da 1'inci Menzil Nakliye Taburunun teşkil edilmesinden sonra Erzurum'da bulunan erzak bu tabura ait nakliye kolları ile Karagöbek ve Hasankale'ye taşınırdı. Aşkale'de 2'nci Nakliye Taburunun teşkil edilmesinden sonra Aşkale'deki erzak, bu tabura ait nakliye kolları vasıtasıyla Erzurum'a ulaştııılırdı. 3'üncü Nakliye Taburu Tercan'da teşkil edilmiş ve Tercan'daki erzak bu tabur bünyesinde bulunan nakliye kolları ile Erzurum'a nakledilirdi. 4'üncü Nakliye Taburu Hınıs'ta teşkil edilmiş ve Hinıs'ta bulunan erzak bu tabura ait nakliye kolları ile Ketvan ve Hasankale'ye nakledilirdi. 5'inci Nakliye Taburu ise Bayburt'ta teşkil edilmiş ve bu tabura ait nakliye kolları ile Bayburt'taki erzak Aşkale'ye ve doğrudan Erzurum'a sevk edilirdi. Menzil bölgesinde yeterli nakliye kolları bulunmadığından Kiğı'daki erzak ise ücretli ahali kolları vasıtasıyla Erzurum'a ulaştırılırd. ${ }^{37}$

Harbin başlangıcında elde yeterli nakliye hayvanı ve nakliye araç gereci bulunmadığından menzil bölgesindeki nakliye hizmetleri başlangıçta oldukça yetersizdi. Özellikle harbin ilk yılında bölgedeki iaşe kaynaklarının yeterli olmasına rağmen nakliye hizmetlerindeki aksaklıklar nedeniyle orduya yeterince erzak ulaştırılamadi. İaşe hususunda zor durumda kalan orduya erzak ulaştırabilmek için erzak 30 kiloluk çuvallar ile insan sırtında taşınmaya başlandı. Amele taburlarından oluşturulan "Yaya Nakliye Kolları" teşkil edildi. ${ }^{38}$ Her bir Yaya Nakliye Kolu 2 zabit ve yaklaşık 400 kişiden oluşurdu. Yaya Nakliye Kollarının sayısının artması ve birkaç nakliye kolunun bir araya gelmesiyle "Yaya Nakliye Taburları" teşkil edildi. Birinci Yaya Nakliye Taburunun merkezi Erzurum, İkinci Yaya Nakliye Taburunun merkezi Aşkale, Üçüncü Yaya Nakliye Taburunun merkezi Erzincan, Dördüncü Yaya Nakliye Taburunun merkezi Selepür (Ocakbaşı), Beşinci

teşkil edildi. Binbaşı Mahmut Bey kumandasında Karabıyık-Erzurum hattında teşkil edilen İkinci Menzil Nakliye Taburu ise 13,14, 15, 16, 17, 18, 19, 20, 21, 22. ve 23. develi nakliye kolundan oluşuyordu. Erzurum-Trabzon hattında Yüzbaşı Bekir Efendi uhdesinde teşkil edilen Üçüncü Menzil Nakliye Taburu, 26, 27, 35, 36, 37, 38, 39. ve 40. develi nakliye kollarında oluşuyordu. Binbaşı Haydar Bey kumandasında Erzurum-Kiğı hattında teşkil edilen Dördüncü Nakliye Taburu ise 1, 2, 3, 4, 6, 11. ve 12. Mekkâreli kollardan oluşuyordu. BDH; Kls. 3055, Dos. H11, Fih. 1, 1-1. BDH; Kls. 3055, Dos. H14, Fih. 5-22a.

${ }^{37}$ Menzile ait nakliye kol ve taburlarının vaziyeti ihtiyaçlara göre her an değişebilirdi. BDH; Kls. 3055, Dos. H14, Fih. 5-13.

${ }^{38}$ BDH; Kls. 3055, Dos. H11, Fih. 1-6a. BDH; Kls. 3055, Dos. H6, Fih.1-21, 1-22. Aziz Samih; s. 9-10. Hafiz Hakkı Paşa, s. 66. 
Yaya Nakliye Taburunun merkezi Erzurum, Altınc1 ve Yedinci Yaya Nakliye Taburlarının merkezi Tercan, Çapakçur Yaya Nakliye Taburunun merkezi Tortum ve Palu Yaya Nakliye Taburunun merkezi ise Erzurum'du. Yukarıdan da anlaşılacağı üzere menzil sınırları içinde 9 Yaya Nakliye Taburu teşkil edilmiş ve bu taburlar bünyesinde ise yaklaşık 5.000 kişi istihdam edilmişti. Büyük bir insan kitlesinin bu taburlarda istihdam edilmesine karşın insan sırtında taşınan erzak miktarı ise oldukça azdı. Bu bakımdan kısa süre sonra Yaya Nakliye Kolları kaldırıldı. Bu kollarda istihdam edilenler ise Yol İnşaat Taburlarında görevlendirildi. ${ }^{39}$

Menzil bünyesinde teşkil edilen kolların yanında Mebus Halet Bey’in başkanlığında teşkil edilen gönüllü menzil nakliye kolları ve hamiyetperver Erzurum halkı da sırtlarında erzak taşıyarak ordunun ihtiyacını karşılamaya çalıştı. ${ }^{40}$

\footnotetext{
${ }^{39}$ Bir kişi ortalama 30 kilo taşıyordu. BDH; Kls. 3055, Dos. H11, Fih. 1-6a. BDH; Kls. 3055, Dos. H6, Fih. 1-21, 1-22. Aziz Samih; s. 9-10. Hafiz Hakkı Paşa; s. 66.

${ }^{40}$ Ordunun nakliye hususunda büyük zorluklarla karşı karşıya bulunduğu dönemlerde Erzurum halkı sırtlarında 20 kıyyelik $(25,5 \mathrm{~kg})$ çuvalları ile Kızılkilise ve Uzun Ahmet Tabyalarına erzak taşıyarak büyük bir hamiyetperverlik örneği göstermiştir. BDH; Kls. 3055, Dos. H5, Fih. 4-1. BDH; Kls. 3055, Dos. H6, Fih. 1-14. Ali Rıza Eti; Bir Onbaşının Doğu Cephesi Günlüğü 1914-1915, Hazırlayan: Gönül Eti, İş Bankası Yay., İstanbul, 2019, s. 125, 139. Hafiz Hakkı Paşa; s. 82.
} 
Fotoğraf 1: Sırtlarında Erzak Taşıyan Kadınlar

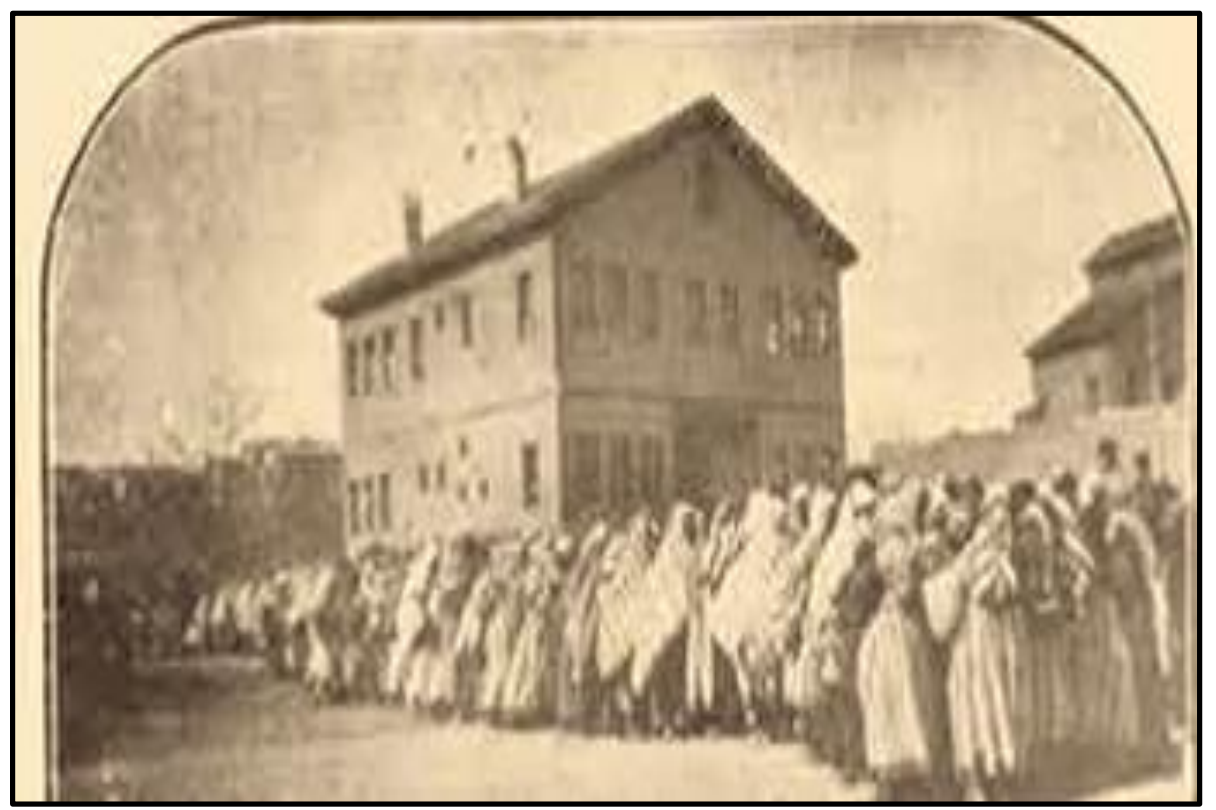

(Kaynak: Harp Mecmuası; S 24, 1 Kânunuevvel 1331, s. 373.)

Nakliye hususunda yapılan tüm bu düzenlemelere rağmen mevcut kollarla ordunun ihtiyaçlarının karşılanması mümkün olmadı. Bu durumda halkı nakliye hizmetinde istihdam edebilmek için nakliye hizmetinde görev yapanlara belirli bir ücret verilmesi yoluna gidildi. Böylece hem Tekâlif-i Harbiye yükümlülüğü çerçevesinde devletçe el konulması gereken yük hayvanları hizmetleri sonunda sahiplerine iade ediliyor hem de hayvan sahiplerine belirli bir ücret ödeniyordu. Başlangıçta özellikle Kiğg-Erzurum menzil hattı gibi menzil nakliye kollarının bulunmadığı veya TercanErzurum hattı gibi nakliye kollarının yetersiz kaldığı hatlarda ücretli ahali kolları istihdam edilmeye başlandı. Kısa sürede ücretli ahali kollarının sayısı hızla arttırıldı. ${ }^{41}$ Ancak eli silah tutan her erkeğin silahaltına alındığ bir dönemde bu hizmet büyük oranda kadın, çocuk ve yaşlı erkeklerin eliyle yapılmaya çalış1lıyordu. Ayrıca nakliyat ücretlerinin ödenebilmesi için günlük yaklaşık 120.000 lira gerekiyordu ki mali bakımdan zor günler geçiren Osmanlı Devleti için büyük bir sorundu. Bununla birlikte özellikle hasat mevsiminin başlamasıyla halkın üretime yönelmesi nakliye hizmetlerini aksatıyordu. Buna rağmen 3. Menzil Bölgesi'nde nakliye

\footnotetext{
${ }^{41}$ Bayburt, Erzincan, Kiğı gibi menzil geri hattından Erzurum'a yapılan nakliyattın hemen hemen yarısı ahali kollarınca gerçekleştirildi. Nitekim 17 Mart 1915 tarihi itibarıyla Erzurum'a yapılan sevkiyatın 43 tonu ahali kollarıyla gerçekleştirilirken 47,7 tonu ise menzile ait kollarla gerçekleştiriliyordu. BDH; Kls. 74, Dos. 376, Fih. 1-81.
}

Askerî Tarih Araştırmaları Dergisi (ATAD), Yıl 2021, Sayı 33:63-92 
hizmetlerinin yürütülmesinde büyük oranda ücretli ahali kollarlyla gerçekleştirildi. ${ }^{42}$

Savaş süresince ikmal hizmetlerinde kullanılmak üzere yeterli motorlu yük aracı da temin edilemedi. Bu bakımdan motorlu araç kullanımı sınırlı kaldı. Nitekim başlangıçta Erzurum-Aşkale hattı üzerinde 1 adet 1,5 tonluk ve 1 adet 3 tonluk olmak üzere 2 yük otomobili kullanılmaya başlandı. Daha sonra bu hat üzerindeki yük otomobillerinin sayısı 8 'e çıkarıld..$^{43}$ Menzil emrine verilen yük otomobillerinin sayıları zamanla arttırıldı. Motorlu yük araçlarının sayısı artınca Kayseri'de bir Otomobil Kumandanlığı oluşturuldu. Sayıları 27'yi bulan bu araçlardan 3 otomobil kolu teşkil edilerek yolların nispeten daha iyi durumda olduğu Ulukışla-Sivas hattında istihdam edildi. Birinci Otomobil Kolu Ulukışla-Develikarahisar hattında, İkinci Otomobil Kolu Develikarahisar-Şarkışla hattında ve Üçüncü Otomobil Kolu ise Şarkışla-Sivas hattında istihdam edildi. ${ }^{44}$

Rusların ileri harekâtı karşısında tutunamayan 3'üncü Ordu, Bayburt hattına kadar geri çekildi. Dolayısıyla ordunun harekât alanın değişmesine bağlı olarak ordunun iaşe sinırları da değişti. Nitekim Erzurum ve Trabzon'un kaybedilmesiyle menzil mıntıkasının sınırları Ardasa (Torul), Gümüşhane, Bayburt, Sansa, Fem, Sorpiran (Demirpınar) ve Kiğı (dâhil) hattı ile Alucra, Altköy, Kuruçay ve Kemah (dâhil) hattı arasında bulunan oldukça dar bir bölgede tertiplendi. Dolayısıyla Ardasa, Gümüşhane, Bayburt, Kelkit, Şiran, Orhanoğulları, Altköy, Refahiye, Melikşerif, Erzincan, Kemah, Ortahan, Kiğ 1 , Fem, Sansa ve Espeverek'te (Verimli) menzil ambarları oluşturuldu. ${ }^{45}$

\footnotetext{
42 Ücretler menzil hattının uzunluğuna göre kg başına ödeniyordu. Nitekim Kiğı-Erzurum hattında her batman için 4 kuruş sağ akçe verilirken Tercan-Erzurum arasında her bir batman iaşe maddesi için 100 para sağ akçe verilirdi. BDH; Kls. 3055, Dos. H1, Fih. 2-3. BDH; Kls. 1131, Dos. 39, Fih. 1, 14, 14-1. BDH; Kls. 3055, Dos. H14, Fih. 5-14.

${ }^{43}$ BDH; Kls. 3055, H2, Dos. 2, Fih. 20. BDH; Kls. 3055, Dos. H4, Fih. 2-4. BDH; Kls. 1129, Dos. 29 , Fih. 10.

${ }^{44} \mathrm{Bu}$ yük otomobilleri daha çok cephane nakliyatı için kullanılırdı. BDH; Kls. 1138, Dos. 69, Fih. 1-37, 1-65, 1-67. BDH; Kls. 1134, Dos. 53, Fih. 3-6, 3-7, 6-2. Birinci Dünya Harbi İdari Faaliyetler ve Lojistik X. Cilt; s. 361.

${ }^{45}$ BDH; Kls. 1131, Dos. 39, Fih. 1-3.
} 
Harita 4: 3'üncü Menzil Bölgesi

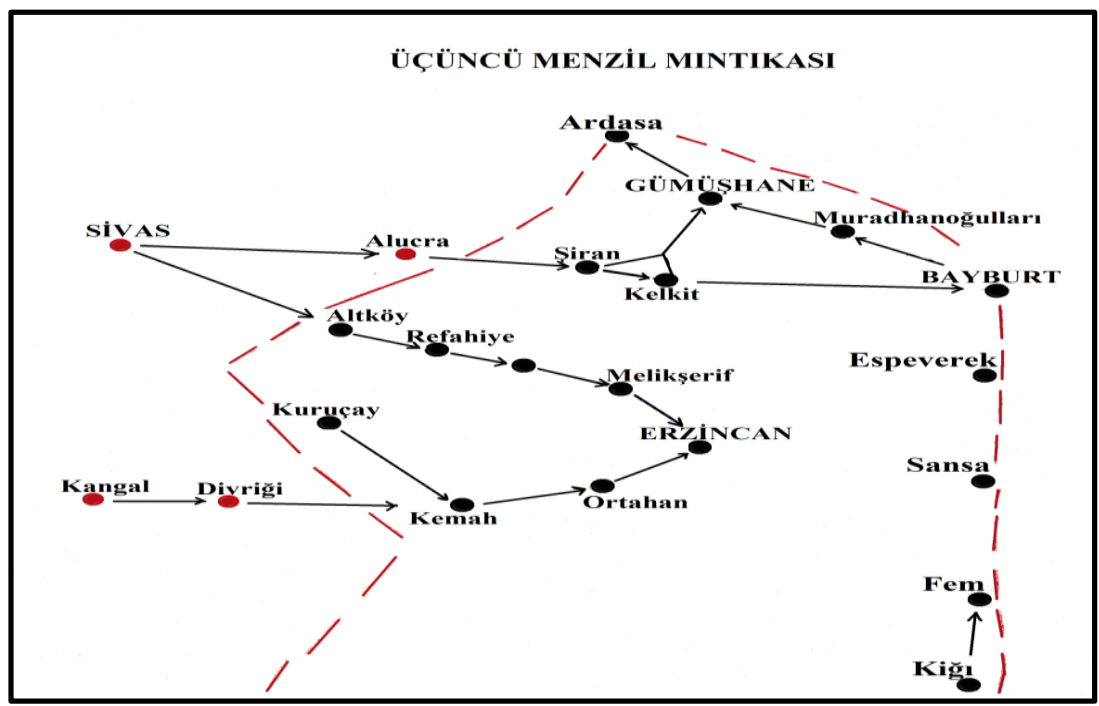

(Kaynak: BDH; Kls. 1131, Dos. 39, Fih. 1-3.)

Sivas vilayetinden gönderilen erzak, Alucra üzerinden Şiran, Kelkit Gümüşhane menzil ambarları üzerinden Ardasa Menzil Ambarına nakledilirdi. Yine Alucra, Şiran ve Kelkit üzerinden sevk edilen erzak Bayburt Menzil Ambarına ve buradan da ordu harekât bölgesine nakledilirdi. Ayrıca Sivas vilayetinden menzil mintıkasının geri hattı üzerinde yer alan Altköy Menzil Ambarına nakledilen erzak buradan Refahiye, Melikşerif, Karanhan ve Erzincan menzil ambarları ve buradan da ordu harekât bölgesinin geri hattı üzerinde yer alan Sansa Menzil Ambarına ulaştırılırdı. Bununla birlikte gerek Kangal ve Divriği üzerinden Kemah Menzil Ambarına gerekse Kuruçay'da toplanan erzak Kemah ve Ortahan ambarları üzerinden Erzincan Menzil Ambarlarına ve buradan da Sansa Menzil Ambarına nakledilerek orduya ulaştırılırdı. Kiğı Ambarında toplanan erzak ise Fem'deki Menzil Ambarına ve buradan da ordu harekât mıntıkasına ulaştırılırd. ${ }^{46}$

Rusların 1916 Temmuz'da Bayburt, Gümüşhane ve Erzincan'ı işgal etmesiyle 3'üncü Menzil Mıntıkası sinırları Erzincan'ın batısından itibaren yeniden tertiplenmeye başland. ${ }^{47}$ (Bk. Ek 2) Bu yeni tertiplenmeye göre menzil mıntıkası Espiye, Balcana, Ağvanıs, Çobanlı, Gemecik ve Nezgeb (dâhil) hattından başlayarak Ayancık, Boyabad, Osmancık, İskilip, Sungurlu,

\footnotetext{
${ }^{46}$ BDH; Kls. 74, Dos. 376, Fih. 1-77. BDH; Kls. 1131, Dos. 39, Fih. 1-3.

${ }^{47}$ BDH; Kls. 1131, Dos. 39, Fih. 1-25.
} 
Yozgat, Mucur ve Ulukışla (dâhil) olacak şekilde yeniden düzenlendi. ${ }^{48}$ 1916 yılı sonlarına doğru Rusya ile gayriresmî bir çatışmazlık devresine girilmesiyle 3'üncü Menzil Teşkilatı bu mıntıkada teşkilatlanmasını hızlıca tamamladi. Nitekim daha önce nakliye hizmetlerini kolaylaştırmak amacıyla oluşturulan hat kumandanlıkları mıntıka kumandanlıklarına dönüştürülerek 3'üncü Menzil Bölgesi'nde 1'inci, 2'nci, 3'üncü, 4'üncü, 6'nc1 ve 7'nci Menzil Mıntıka Müfettişlikleri olmak üzere 6 Menzil Mıntıka Müfettişliği teșkil edildi. ${ }^{49}$ Böylece her mıntıkada bulunan menzil ambarları ve menzil nakliye kolları bu mıntıka müfettişliklerinin uhdesine verildi. Birinci Menzil Mıntıka Müfettişliği bünyesinde Everek, Aziziye, Kangal, Divriği ve Nezgeb'de menzil ambarları tesis edilerek iaşe maddeleri menzile ait nakliye kolları ve ahaliye ait nakliye kolları peyderpey ordu harekât mıntıkasını gerisinde bulunan Nezgeb ambarına sevk edilirdi. $\mathrm{Bu}$ mıntıka dâhilinde Kangal-Divriği hattında 3 kağnı kolu, 10 merkepli kol ve 1 mekkâreli kol istihdam edildi. $^{50}$

İkinci Menzil Mintıka Müfettişliği bünyesinde Yozgat, Köhne, Yenihan, Şarkışla, Sivas, Kayadibi, Zara, Şerefiye, Koçhisar, Ümraniye ve Gemecik'te menzil ambarları tesis edildiği Șarkışla-Sivas hattında Birinci Otomobil Kolu ile 1 develi kol, 1 mekkâreli kol, 1 merkepli kol, 1 kağnı kolu ve 1 at arabalı kol istihdam edildi. Yenihan-Sivas hattında 1 merkepli kol, 1 at arabalı kol ve 4 kağnılı kol görevlendirildi. Sivas-Zara hattında ise 1 kağnılı kol, 6 at arabalı kol, 1 mekkâreli kol ve 1 merkepli kol istihdam edildi. Zara-Ümraniye arasında 5 develi kol, Zara-Suşehri hattında ise 4 develi kol görev yaparken Ümraniye-Gemecik hattında ise 5 mekkâreli kol istihdam edildi. ${ }^{51}$

Üçüncü Menzil Mıntıka Müfettişliği bünyesinde ise Erbaa, Teke, Niksar, Tokat, Turhal, Zile, Kazalapa (Mutluca), Reşadiye, Mudasun (Gökdere), Koyulhisar, Kalei Zir (Aşağıkale), Koçhisar, Suşehri, Tönük, Karahisar (Şebinkarahisar), Ortaköy, Ağvanis (Gölova), Tamdere ve Balcana'da menzil ambarları teşkil edildi. Niksar-Reşadiye hattında 2 kağnı kolu, 1 at arabalı kol, 2 mekkâreli kol, 2 develi kol, 7 merkepli menzil nakliye kolu görev yapıyordu. Reşadiye-Koyulhisar hattında 17 kağnı kolu görev yaparken Çilehane-Koyulhisar hattında ise 1 develi ve 7 merkepli kol görev yapıyordu. Kalei Zir-Suşehri ve Koyulhisar-Suşehri hattında 6 develi,

\footnotetext{
${ }^{48}$ BDH; Kls. 1138, Dos. 69, Fih. 1-52, 1-57, 1-65, 1-67, 1-69. BDH; Kls. 2469, Dos. 333, Fih. 3-35.

${ }^{49} \mathrm{Bu}$ mıntıka müfettişliklerine ait haritalar için bk. Yavuz Selim Çeloğlu; "Birinci Dünya Savaşı'nda Doğu Cephesi'nin Lojistik Organizasyonu: 3. Menzil Müfettişliği”, Çanakkale Araştırmaları Türk Yılllğı Dergisi, Y11 17, S 29, Güz 2020, s. 17-27.

${ }^{50}$ BDH; Kls. 1138, Dos. 69, Fih. 1-52, 1-57, 1-65, 1-67, 1-69. BDH; Kls. 2469, Dos. 333, Fih. 3-35. BDH; Kls. 3028, Dos. 13, Fih. 2.

${ }^{51}$ BDH; Kls. 1138, Dos. 69, Fih. 1-52, 1-57, 1-65, 1-67, 1-69. BDH; Kls. 2469, Dos. 333, Fih. 3-35. BDH; Kls. 3028, Dos. 13, Fih. 2.
} 
4 mekkâreli ve 10 merkepli nakliye kolu istihdam edildiği gibi SuşehriKarahisar hattında ise 7 at arabalı, 1 kağnılı ve 5 mekkâreli kol istihdam edilmişti. Karahisar-Balcana ve Karahisar-Ağvanis hattında 7 at arabalı, 1 kağnılı, 2 mekkâreli kol görev yapıyordu. ${ }^{52}$

Dördüncü Menzil Mintıka Müfettişliği bünyesinde Sinop, Bafra, Samsun, Çarşamba, Giresun, Ordu, Alaçam, Kulakkaya ve Habsamana'da (Gölköy) menzil ambarları tesis edildi. Bu menzil mıntıkasının Karadeniz kıyısında bulunduğundan nakliye hizmetlerinin bir bölümü deniz yoluyla gerçekleştirilirdi. Sahil boyunca Dördüncü Mıntıka Müfettişliği emrinde Giresun, Ordu, Ünye, Terme, Samsun ve Sinop'ta Menzil İskele Kumandanlıkları oluşturuldu. Menzil bünyesinde yer alan deniz nakliye araçları daha çok yelkenli kayıklardan oluşurdu. Nitekim Sinop'ta 3, Samsun'da 2, Ünye'de 3, Ordu'da 3, Giresun'da 2 ve Espiye'de 3 yelkenli kayık kolu teşkil edildi. Bununla birlikte menzil bünyesinde 3 motorbot kolu bulunuyordu. Doğrudan menzile ait kayık ve motorbotların yanında ahaliden ücret mukabilinde kiralanan kayıklar da nakliyatta kullanıldı. ${ }^{53}$

Dördüncü Menzil Mıntıka Müfettişliği bünyesindeki kara yolu nakliyatının yapılabilmesi için de Ordu-Habsamana hattında 3 merkepli kol, Samsun-Kavak hattında 1 merkep, 1 mekkâreli ve 1 kağnı kolu istihdam edilirken Kavak-Havza hattında ise 3 kağnı kolu, 3 at arabalı kol ve 5 merkepli kol istihdam edildi. Ayrıca Ordu-Habsamana hattında 3 merkepli kol Giresun-Kulakkaya hattında 1 mekkâreli kol ve Kulakkaya-Tamdere hattında ise 3 mekkâreli kol istihdam edildi. ${ }^{54}$

Altıncı Menzil Mıntıka Müfettişliği bünyesinde Çorum, Mecitözü, Osmancık, Merzifon, Boyabad, Vezirköprü, Havza, İskilip, Sungurlu, Alaca ve Lâdik'te menzil ambarları tesis edildi. Amasya-Tokat hattında 3 mekkâreli ve 7 at arabalı menzil nakliye kolu; Amasya-Zile hattında 3 kağnılı, 1 at arabalı, 1 mekkâreli ve 2 merkepli kol; Çorum-Amasya hattında 8 merkepli, 1 mekkâreli kol; Çorum-Merzifon hattında 5 merkepli kol; Merzifon-Amasya hattında 2 at arabalı, 1 kağnılı ve 1 merkepli kol; Merzifon-Havza hattında 1 merkepli ve 1 at arabalı kol istihdam edildi. ${ }^{55}$

Yedinci Menzil Mıntıka Müfettişliği bünyesinde ise Ulukışla, Niğde, İncesu, Kayseri, Boğazlıyan, Sultanhan ve Gemerek'te menzil ambarları

\footnotetext{
${ }^{52}$ BDH; Kls. 1138, Dos. 69, Fih. 1-52, 1-57, 1-65, 1-67, 1-69. BDH; Kls. 2469, Dos. 333, Fih. 3-35. BDH; Kls. 3028, Dos. 13, Fih. 2.

533 Temmuz 1917 tarihi itibarıyla Dördüncü Menzil Mıntıka Müfettişliği bünyesinde bulunan ahali kayıklarının sayısı 158 idi. BDH; Kls. 1134, Dos. 53, Fih. 6-1.

${ }^{54}$ BDH; Kls. 1138, Dos. 69, Fih. 1-52, 1-57, 1-65, 1-67, 1-69. BDH; Kls. 2469, Dos. 333, Fih. 3-35. BDH; Kls. 3028, Dos. 13, Fih. 2.

${ }_{55}$ BDH; Kls. 1138, Dos. 69, Fih. 1-52, 1-57, 1-65, 1-67, 1-69. BDH; Kls. 2469, Dos. 333, Fih. 3-35. BDH; Kls. 3028, Dos. 13, Fih. 2.
} 
teşkil edildi. Bu menzil mıntıkası üzerinde ise Ulukışla-Niğde hattında 2, 4 ve 5'inci Otomobil Kolu ile 1 kağnı ve 1 at arabalı kol; NiğdeDevelikarahisar hattında 4 kağnı kolu; Develikarahisar-Kayseri hattında 3'üncü Otomobil Kolu, 1 develi, 4 kağnılı ve 1 at arabalı kol; KayseriGemerek hattında 1 mekkâreli, 2 merkepli ve 1 kağnılı kol; GemerekŞarkışla hattında ise 3 develi ve 1 kağnılı kol nakliye hizmetinde istihdam edildi. ${ }^{56}$ Böylece menzil genelinde 37 arabalı kol, 45 mekkâreli kol, 91 merkep kolu, 49 kağnı kolu, 16 yelkenli kayık kolu, 3 motorbot kolu ve 5 otomobil kolu nakliye hususunda istihdam edilmiş oldu. ${ }^{57}$

Menzil Müfettişliği emrinde yeterli miktarda nakliye hayvanı bulunmadığından yeterli miktarda nakliye kolları teşkil edilemedi. Dolayısıyla hizmetlerinin önemli bölümü ücretli ahali kolları vasıtasıyla gerçekleştirildi. ${ }^{58}$ Nitekim 1916 yılı itibarıyla, yalnızca ordunun günlük 180 tonluk erzak ihtiyacını karşılayabilmek için 2.500 tonluk nakliye vasıtalarına ihtiyaç vard. Ancak ordu emrinde toplam 80 tonluk 20 adet yük otomobili, 519 tonluk menzil ulaştırma kolları, 359 tonluk menzil demirbaş ulaştırma kolları ve 246 tonluk Sivas vilayeti nakliye kolları olmak üzere toplam 1.234 tonluk nakliye kolları mevcuttu. Gerek ordu gerekse geri hizmetlerde istihdam edilenlerin günlük erzak ihtiyacı da hesaba katıldığında menzil bölgesindeki nakliyat için yaklaşık 2.000 tonluk nakliye vasıtasına ihtiyaç vardı. Ordu bu nakliye ihtiyacını karşılayabilmek için yük hayvanlarına el koymak yerine cüzi bir meblağ karşılı̆̆ında hayvanlar, sahipleri ile birlikte nakliye hizmetinde istihdam edilmeye başlandı. Böylece hayvan sahipleri, harp yükümlülüğ̈̈ gereği hayvanlarını devlete vermek yerine kendileri ile birlikte cüzi de olsa belli bir ücret mukabilinde bir süreliğine ordu nakliye hizmetinde görev alacaktı. Böylece hayvan sahipleri hem hayvanlarını devlete vermek durumunda kalmayacak hem de belli ücret alabilecekti. ${ }^{59}$

Ordu nakliye hizmetlerinin önemli bir bölümü ücretli halk kolları ile gerçekleştirilse de bu uygulamanın aksayan yönleri bulunuyordu. Nitekim eli silah tutan herkes silahaltına alındığından geride yaşı erkekler, kadın ve çocuklar kalmıştı. Dolayısıyla halk kollarında istihdam edilenlerin büyük bölümü yaşlı erkekler, kadın ve 8-10 yaşından büyük çocukların eliyle yapılmaya çalış1ıyordu. Ayrıca ahali kollarına verilmesi gereken ücret için önemli miktarda paraya ihtiyaç vardı. Bununla birlikte özellikle hasat

\footnotetext{
${ }^{56}$ BDH; Kls. 1138, Dos. 69, Fih. 1-52, 1-57, 1-65, 1-67, 1-69. BDH; Kls. 2469, Dos. 333, Fih. 3-35. BDH; Kls. 3028, Dos. 13, Fih. 2.

${ }^{57}$ BDH; Kls. 1138, Kls. 69, Fih. 1-67.

${ }^{58}$ BDH; Kls. 3055, Dos. H10, Fih. 5-21, 21a, 22, 22a. BDH; Kls. 3055, Dos. H2, Fih. 2-23a.

${ }^{59}$ BDH; Kls. 1131, Dos. 39, Fih. 1, 1-2, 1-2a, 1-10. BDH; Kls. 3031, Dos. 22, Fih. 1, 1-1, 1-2, 1-3, 1-4, 1 5, 1-6, 1-7, 1-8, 1-9, 1-10, 1-11, 1-12, 1-13, 1-14, 1-15, 1-16, 1-17, 1-18, 1-19. BDH; Kls. 1131, Dos. 39, Fih. 14, 14-1.
} 
mevsiminde, ahali kollarının sayısının azalması gibi nedenlerden ötürü ücretli ahali kollarından yeterince istifade edilemedi. ${ }^{60}$

\section{c. Ana Vatan Bölgesi'nde Depolama ve Nakliye Hizmetlerinin Yürütülmesi}

Menzil mıntıkasından başlayarak ordu iaşe bölgesini kapsayan bölge Ana Vatan Bölgesi veya Dâhili Memleket Bölgesi olarak adlandırılırdı. Dolayısıyla 3'üncü Ordu menzil mıntıka hududunu teşkil eden İspir, Bayburt, Tercan, Kiğı ve Hınıs kaza hududu (hariç) ile Bitlis, Van, Diyarbekir, Harput ve Musul vilayetleri hudutlarını (dâhil) içine alan bölge Ana Vatan Bölgesi olarak belirlenmişti. ${ }^{61}$ Ana Vatan Bölgesi'ndeki iaşe maddelerinin toplanması, depolanması ve menzil mintıkasındaki ambarlara kadar ulaştırılmasında vilayet ve sancak idari amirleri olan vali ve mutasarrıfların uhdesine verilmişti. Vilayetler ve sancak ambarlarında toplanan erzak öncelikle ana ikmal yolları üzerinde bulunan ambarlara aktarılır ve buradan da vilayete ait nakliye kolları veya ücretli ahali kollarından oluşan kollar vasıtasıyla menzil hududunda bulunan ambarlara aktar111rd1.

Başlangıçta 3'üncü Ordu iaşe bölgesi içinde yer alan Diyarbekir vilayetinden toplanan iaşe maddeleri, bu vilayete ait nakliye kolları vasitasıyla Elâziz'e veya Palu, Kiğı ve Çerme (Yedisu) ambarlarına nakledilirdi. Elâzı ğ vilayeti dâhilinde toplanan iaşe maddeleri ise bir kısmı Eğin ambarı üzerinden Erzincan'a nakledilirken bir kısmı da Palu ambarına ve buradan da Kiğı ve Çerme (Yedisu) ambarlarına nakledilirdi. 3'üncü Ordu iaşe sınırları içinde bulunan Musul vilayetinden toplanan iaşe maddeleri ise Cizre ve Bitlis ambarları üzerinden menzil sınırları içinde yer alan Hınıs, Mescitli, Ketvan ve Hasankale ambarlarına nakledilirdi. ${ }^{62}$

Bu nakliyat esnasında Musul vilayetinden Cizre'ye yapılacak nakliyat Musul vilayetinin sorumluluğunda bulunurken Cizre'den Bitlis ambarlarına ve buradan da Hinıs ambarlarına kadar yapılacak sevkiyat ise Bitlis vilayetinin uhdesindeydi. Ayrıca Diyarbekir'den Elâziz'e, Palu ve Kiğı ambarlarına yapılacak sevkiyat Diyarbekir vilayetinin; Elâziz vilayetinden Erzincan, Palu ve Kiğı ambarlarına yapılacak sevkiyat Elâziz vilayetinin;

\footnotetext{
${ }^{60}$ BDH; Kls. 3055, Dos. H13, Fih. 4-25. BDH; Kls. 1131, Dos. 39, Fih. 1, 14, 14-1.

${ }^{61}$ Ana Vatan Bölgesi'ni gösteren harita için bk. Harita 4. BDH; Kls. 3055, Dos. H1, Fih. 1-1a, 1- 10a. BDH; Kls. 3055, Dos. H11, Fih. 1-32.

${ }^{62} 17$ Mart 1915 tarihi itibarıyla Ana Vatan Bölgesi'nden menzil bölgesine yapılan günlük nakliyat 155,5 ton olarak hesaplanmıştır. BDH; Kls. 74, Kls. 376, Fih. 1-81. BDH; Kls. 3055, Kls. H9, Fih. 4-13. BDH; Kls. 3055, Dos. H5, Fih. 4, 4-1. BDH; Kls. 3055, Dos. H4, Fih. 2, 2-1a. BDH; Kls. 3055, Dos. H1, Fih. $1-11$.
} 
Trabzon vilayetinden toplanan erzakın ise Bayburt'a ulaştırılması Trabzon vilayetinin uhdesine verilmişti. ${ }^{63}$

Ana Vatan Bölgesi'ndeki iaşe maddelerinin temin edilmesinde veya bunların ileriye nakledilmesinde mülki idare amirleri olan vali, mutasarrıf ve kaymakamların özel çaba ve gayretleri belirleyici olmuştur. Dolayısıyla bölgedeki mülki amirlerin özel çaba ve gayretleri, iaşe ve ikmal hizmetlerinin işleyişini doğrudan etkilemiştir. ${ }^{64}$

Orduların ihtiyaçlarını yalnızca kendilerine ayrılan iaşe bölgelerinden karşılayabilmeleri mümkün değildi. Dolayısıyla orduların iaşe ihtiyaçlarının bir bölümü merkezden gönderilen iaşe maddeleri ile karşılanırdı. Levazımatı Umumiye Dairesi ve Menzil Genel Müfettişliği vasıtasıyla yurt içi veya yurt dışından ${ }^{65}$ temin edilen iaşe maddeleri peyderpey ordulara aktarılırdı. Nitekim 3'üncü Ordunun ihtiyaçlarının önemli bir bölümü, yani yaklaşık $1 / 4$ 'ü merkezden gönderilen erzakla karşıland1. ${ }^{66}$

Harbin başlangıcında 3'üncü Ordunun lojistik desteği Trabzon Limanı'na dayanılarak düzenlenmiş ve planlanmalar da bu yönde yapılmıştı. Bölgenin en büyük limanının Trabzon' da bulunması ve buranın gerek askerî gerekse ticari açıdan bölgenin en gelişmiş kara yolu ile desteklendiğinden ordunun lojistik ikmal planlanması bu güzergâh üzerinden yapı1ld $1 .{ }^{67}$

Deniz yoluyla Trabzon İskele Kumandanlığına teslim edilen iaşe maddeleri buradan öncelikle şehir merkezindeki ambarlara aktarılırdı. Ancak Rusların Trabzon şehir merkezini bombalaması ile burada bulunan erzak, Hamsiköy (Cevizlik), Maçka, Deliklitaş ve Hacı Mehmet gibi ateş hattının dışına inşa edilen ordu aktarma ambarlarında nakledilmeye başlandı.

\footnotetext{
${ }^{63}$ BDH; Kls. 3055, Dos. H4, Fih. 2. BDH; Kls. 3055, Dos. H2, Fih. 2-26. BDH; Kls. 3055, Dos. H11, Fih. 1-7. BDH; Kls. 3055, Dos. H11, Fih. 1-7. BDH; Kls. 1129, Dos. 29, Fih. 10-1. BDH; Kls. 3055, Dos. H14, Fih. 5-22a. BOA; DH. ŞFR., 53/33.

${ }^{64}$ Dönemin Trabzon Valisi Cemal Azmi Bey, Erzurum Valisi Tahsin Bey ve Bitlis Valisi Mustafa Bey gibi hamiyet sahibi mülki amirlerden bazılarıydı. BDH; Kls. 3055, Dos. H2, Fih. 2-4a, 2-6. BOA; DH. İ. UM., 82/1. BDH; Kls. 3055, Dos. H4, Fih. 2-15a. BDH; Kls. 3055, Dos. H13, Fih. 4-8. Guze; s. 5, 89. Aziz Samih; s. 10. Hafiz Hakkı Paşa; s. 104.

${ }^{65}$ Birinci Dünya Savaşı'nın başlamasıyla ithalat yolları büyük oranda kapanmış ve Osmanlı Devleti ihtiyaçlarını büyük oranda kendi kaynaklarıyla karşılamak zorunda kalmıştır. Zafer Toprak; İttihatTerakki ve Cihan Harbi: Savaş Ekonomisi ve Türkiye'de Devletçilik 1914-1918, Homer Kitabevi, İstanbul, 2003, s. 177-178.

${ }^{66}$ BOA; DH. ŞFR., 56/97. Çakmak; s. 309.

${ }^{67}$ Çakmak; s. 255. Birinci Dünya Harbi İdari Faaliyetler ve Lojistik X. Cilt; s. 26. Edward J. Erickson; Size Ölmeyi Emrediyorum! Birinci Dünya Savaşı'nda Osmanlı Ordusu, çev. Tanju Akad, 2. Baskı, Kitap Yayınevi, İstanbul, 2003, s. 183.
}

Askerî Tarih Araştırmaları Dergisi (ATAD), Yıl 2021, Sayı 33:63-92 
Bu ambarlarda depolanan iaşe maddeleri ise peyderpey 3'üncü Ordu lojistik merkezi olan Erzurum'a aktarılırd1. ${ }^{68}$

Rusların Özellikle Mithat Paşa, Karadeniz, Bahriahmer ve Bezmiâlem gibi önemli Türk nakliye gemilerini batırması ve Osmanlı donanmasının belkemiğini oluşturan Yavuz savaş gemisinin 26 Aralık 1915 tarihinde Rus torpilleri sonucu yaralanarak savaş dışında kalmasıyla merkezden bölgeye yapılan nakliyat büyük oranda kesintiye uğradı. ${ }^{69}$ Rusların Karadeniz'i kontrol etmesiyle gerilerden bölgeye yapılan nakliyat büyük oranda sekteye uğrasa da Doğu Karadeniz sahilindeki nakliyat tamamen engellenememişti. Samsun, Giresun, Ordu, Ünye ve Trabzon arasındaki deniz ulaşımı yelkenli kayıklar, taka, mavna ve salapurya gibi küçük deniz taşıtlarıyla yapılmaya devam edildi. ${ }^{70}$

Deniz yolunun tehlikeye girmesiyle 1915 y1lı baharından itibaren demir yolları daha aktif olarak kullanılmaya başlandı. İstanbul'daki Levazımatı Umumiye ambarları ve Menzil Genel Müfettişliği ambarlarında toplanan ikmal maddeleri Anadolu demir yolu hattı ile Ulukışla İstasyonu'na nakledilir, buradan da kara yolu ile ordu harekât bölgesine aktarılırdı. Cepheye doğrudan ulaşan bir demir yolu hattı bulunmadığından merkezden yapılan sevkiyat ordu harekât bölgesinin $859 \mathrm{~km}$ gerisinde bulunan Ulukışla İstasyonu üzerinden gerçekleştiriliyordu. ${ }^{71}$ Ancak bu demir yolu hattı ile yalnızca 3'üncü Ordunun değil Suriye Cephesi'ndeki 4'üncü Ordu ile Irak Cephesi'ndeki 6'ncı Ordunun ihtiyaçları da karşılanıyordu. Ayrıca 1916 yılı Nisan'ından itibaren 2'nci Ordunun da Kafkas Cephesi'ne intikal ettirilmesiyle bu dört ordunun ihtiyaçları tek hat olarak inşa edilen Anadolu demir yolu ile yapılmaya çalışıldı. Altyapısı oldukça yıpranmış, vagon ve kömür ihtiyacı bir türlü karşılanamamış bu hat ile ikmal hizmetlerinin

\footnotetext{
68 Trabzon'dan Hamsiköy'e uzanan bir dekovil hattının inşa edilmiş olması bu ambarlara yapılan nakliyatı nispeten kolaylaştırıldı. BDH; Kls. 3055, Dos. H9, Fih. 4-2. BDH; Kls. 3055, Dos. H1, Fih. 1, 1 1. BDH; Kls. 3055, Dos. H9, Fih. 4-13. Çakmak; s. 255. Guze; s. 5.

${ }^{69}$ Guze; s. 72. Çakmak; s. 262, s. 305. Sadık Erdaş; "Hatıralar Ișığında Kafkas Cephesi'nde Yaşanan Temel Sorunlar ve Gözlemler", 100. Y1l Münasebetiyle Birinci Dünya Savaşı'nda Kafkas (Doğu) Cephesi Uluslararası Sempozyumu, Erzurum, 24-27 Eylül 2014, s. 678. Şaban Ortak; "Sarıkamış Harekâtı Öncesi Kafkas Cephesi’ne Deniz Nakliyatı ve Yaşanan Deniz Savaşları”, 100. Yılı Münasebetiyle I. Dünya Savaşı'nda Kafkas (Doğu) Cephesi Uluslararası Sempozyumu, C 1, Erzurum, 25-27 Eylül 2014, s. 293-294.

${ }^{70}$ BOA; DH. ŞFR, 68/194. Liman von Sanders; s. 54. Birinci Dünya Harbi İdari Faaliyetler ve Lojistik X. Cilt; s. 89. Çakmak; s. 305. Ortak; s. 296-297. Önder Duman; "Birinci Dünya Savaşı Yıllarında Karadeniz'de Osmanlı Kayık Taşımacılığı”, Uluslararası Karadeniz İnceleme Dergisi, 2007, 1 (2), s. 137 147.

${ }^{71}$ Savaştan önce yapımına başlanan Ankara-Sivas demir yolu hattının yapımı tamamlanamadığından demir yolu nakliyatı için en uygun istasyon Ulukışla İstasyonu'ydu. BOA; DH. ŞFR., 50-117. BDH; Kls. 1129, Dos. 29, Fih. 1. Çakmak; s. 255, 305. Guze; s. 6, 89. Birinci Dünya Harbi İdari Faaliyetler ve Lojistik X. Cilt; s. 783. Kafkas Cephesi 3'üncü Ordu Harekâtı; s. 30.
} 
sorunsuz işleyebilmesi mümkün olmadığından hat üzerinde büyük yığılmalar yaşand1. ${ }^{72}$

\section{3. İaşe Hususunda Yaşanan Sorunlar}

Osmanlı Devleti harp esnasında askere verilmesi gereken günlük istihkak miktarını yasal olarak belirlemişti. Dolayısıyla harp zamanında her askere günde yaklaşık 3 bin kalorilik bir tayinatın verilmesi gerekiyordu. ${ }^{73}$ Ancak cephenin açılmasından itibaren ordu iaşe hususunda büyük sorunlarla karşı karşıya kaldığından harp süresince askerin günlük istihkak miktarı hiçbir zaman tam olarak karşılanamadı. Askerin en temel besin kaynağ1 ekmek ve ekmek yerine askere yedirilen peksimet dahi çoğu zaman yarım tayınat olarak verilebildi. Hatta zaman zaman üç askere yalnızca bir peksimet verilebiliyordu. ${ }^{74}$ Harp esnasında askere verilen günlük ekmek miktarı hakkında Kafkas Cephesi'nde görev yapan Hasan Remzi Fertan şunları aktarmaktadır: "... Cephede bulunduğum bir sene içinde erin tam ekmek aldığını görmedim." 75

Askerin ekmek ihtiyacı gibi günlük erzak istihkakı da yetersizdi. Nitekim askerin beslenmesinde büyük önem taşıyan sıcak yemek nadiren verilebiliyordu. Askerin günlük yiyeceği çoğunlukla yumruk kadar siyah bir ekmek veya peksimet ile bir miktar kavurmadan ${ }^{76}$ ibaret olsa da askerin yemeği çoğu zaman un çorbası, bulgur, kuru fasulye ve bakladan oluşuyordu. Sebze ve meyve ise hemen hemen hiç verilemiyordu. Harp esnasındaki bu tekdüze ve yetersiz beslenme, ordu içinde bazı hastalıkların yayılmasına neden oldu. Zira askere sebze ve meyve verilemediğinden iskorbüt hastalığı orduda yaygın olarak görülmüştür. ${ }^{77}$ Ayrıca açlık ödemi ${ }^{78}$ gibi doğrudan yetersiz beslenmeden kaynaklanan hastalıkların yanında yetersiz beslenme sonucu zayıf ve perişan durumdaki askerlerin bedeni,

\footnotetext{
72 Çakmak; s. 305. İzzettin Çalışlar; On Yıllık Savaşın Günlügü̈, Balkan, Birinci Dünya ve İstiklal Savaşları, haz. İsmet Görgülü-İzzeddin Çalışlar, Yapı Kredi Yay., İstanbul, 1997, s. 151. Ahmet İzzet Paşa; Feryadım, Yay. haz. S. İ. Furkaç, C I, Nehir Yay., İstanbul, 1992, s. 249-250. Birinci Dünya Harbi İdari Faaliyetler ve Lojistik X. Cilt; s. 331. Mehmet Sinan Özgen; Bolvadinli Mehmet Sinan Bey'in Harp Hatıraları, Yay. haz. Servet Avşar, Hasan Babacan, Muharrem Bayar, İstanbul, 2011, s. 46-47.

${ }^{73}$ Yavuz Selim Çeloğlu; Çanakkale Cephesi'nde 5. Ordunun İaşesi, s. 85-86.

${ }^{74}$ BDH; Kls. 3055, Dos. H6, Fih.1-16a. Ali Riza Eti; s. 45, 70, 72, 75, 105.

${ }^{75}$ Hasan Remzi Fertan; Hasan Remzi Fertan'ın Harp Hatıraları (Çanakkale, Kafkas, Filistin Cepheleri ve İstiklal Harbi), haz. Lokman Erdemir, İstanbul, 2016, s. 75. Halil Ataman; Harp ve Esaret (Doğu Cephesi'nden Sibirya'ya), haz. Ferhat Ecer, İstanbul, 2011, s. 61. Vasfi Şensözen; I. Dünya Savaşı Yılları ve Kafkas Cephesi Anıları, Yay. haz. Saro Dadyan, Okyanus Yay., İstanbul, 2013, s. 82.

${ }^{76}$ Etlik hayvan temininde büyük sıkıntı yaşanmıyordu. Zira bölgede hayvan sayısı ve hayvanların canlı olarak ordu gerisine kadar nakledilebilmesi nedeniyle etlik hayvan temininde büyük sıkıntı çekilmiyordu. Birliklerde kesilen hayvanlar kavurma hâline getirilirdi. Böylece bozulmadan uzun müddet saklanabilirdi. Hafız Hakkı Paşa; s. 101, 103. Guze; s. 3. Ali Rıza Eti; s. 45. Halil Ataman; s. 74. Çakmak; s. 309.

${ }^{77}$ Halil Ataman; s. 99.

${ }^{78}$ Abdülkadir Noyan; Son Harplerde Salgın Hastalıklarla Savaşlarım, s. 97.
} 
ölümcül olmayan hastalık veya yaralanmalara direnç gösteremediğinde hasta ve yaralılar arasında ölümle sonuçlanan vaka sayısı oldukça fazlaydı. ${ }^{79}$ Bununla birlikte ordudaki büyük iaşe sorunu, askerlerin maneviyatını büyük ölçüde kırmış olduğundan orduda firar olayları sık görülüyordu. ${ }^{80}$

3'üncü Ordunun iaşe hususunda büyük zorluklarla karşılaşmasının çeşitli sebepleri vardı. Bunlardan biri de harp için yeterli stoklamanın yapılamamasıydı. Seferberliğin ilanı ile harbin başladığı tarih arasındaki yaklaşık 3 aylık dönemde yeterli stoklama yapılamadığından daha harbin başından itibaren orduda iaşe sıkıntısı baş gösterdi. ${ }^{81}$ Nitekim kış mevsiminin yaklaşmasıyla külli miktarda iaşe depolanması gerekirken 3'üncü Ordu için yaklaşık 1.250 tonluk bir stok yapılabilmişti. Bu miktar ise ordunun yalnızca birkaç günlük ihtiyacını karşılayabilirdi. ${ }^{82}$ Oysa seferberliğin ilanından itibaren yaklaşık üç aylık bir dönem iyi değerlendirilerek yapılacak stoklama ile ordu uzun müddet erzak sikıntıs1 yaşamadan harbi devam ettirebilirdi.

Bununla birlikte harbin başlangıcında oldukça geniş bir bölge 3'üncü Ordunun iaşe bölgesi olarak belirlenmesine rağmen ordunun Ruslar karşısında tutunamayıp sürekli geri çekilmesiyle ordunun iaşe bölgesinin büyük bölümü Rus işgaline uğradı. 3'üncü İaşe Bölgesi'nin daralmasıyla bölgedeki iaşe kaynakları da yetersiz kald1 ${ }^{83}$ Özellikle ordunun iaşe ihtiyacının büyük bölümünü karşılayan Erzurum ve Trabzon vilayetlerinin kaybedilmesiyle iaşe hususu çok daha vahim bir hâl aldı ${ }^{84}$ Ayrıca ülke topraklarının büyük bölümünün yitirilmesiyle ordu, bölgedeki iaşe kaynaklarından mahrum kaldığı gibi bölge halkının önemli bir bölümünün iç bölgelere göç etmesiyle büyük bir muhacir sorunu ortaya çıtı. Dolayısıyla bir yandan ordunun ihtiyaçları karşılanmaya çalışılırken bir yandan da muhacir duruma düşen halkın iaşe ve ikmal ihtiyacı karşılanmaya çalışıldı ${ }^{85}$

\footnotetext{
${ }^{79}$ Kemal Özbay; Türk Asker Hekimliği Tarihi ve Asker Hastaneleri, C 1, Yörük Basımevi, İstanbul, 1976, s. 172. Tevfik Salim; "Büyük Harp’te Kafkas Cephesi'ndeki Sihhi Vaziyete Dair Bir Tetkik", Askerî Mecmua, C VI, S 97, İstanbul, 1335, s. 503-504.

${ }^{80}$ Guze; s. 86-87. Halil Ataman; Harp ve Esaret (Doğu Cephesi’nden Sibirya'ya), haz. Ferhat Ecer, İstanbul, Haziran 2011, s. 57-58.

${ }^{81}$ BDH; Kls. 3055, Dos. H11, Fih. 1-6a. BDH; Kls. 3055, Dos. H11, Fih. 1-32, 1-36, 1-37, 1-45. BDH; Kls. 3055, Dos. H10, Fih. 5-43. BOA; DH. ŞFR, 52/13. BOA; DH. ŞFR. 49/ 256. Birinci Dünya Harbi İdari Faaliyetler ve Lojistik X. Cilt; s. 134-35. Tevfik Salim; s. 492, 502. Aziz Samih; s. 35.

${ }^{82}$ Mehmed Emin; s. 35.

${ }^{83}$ BDH; Kls. 1131, Dos. 39, Fih. 14-2.

${ }^{84}$ Erickson; s. 181-183. Guze; s. 65.

${ }^{85}$ BOA; DH. ŞFR. 67/6. Aziz Samih; s. 15. Guze; s. 89. Birinci Dünya Harbi İdari Faaliyetler ve Lojistik X. Cilt; s. 362. Süleyman Tekir; "Birinci Dünya Savaşı'nda Doğu Anadolu ve Doğu Karadeniz Rus İşgali Bölgelerinden Yapılan Göçler”, Çağdaş Türkiye Tarihi Araştırmaları Dergisi, XVI/32, (Bahar/Spring2016), s. 43-65. Sadık Erdaş; s. 687-688.
} 
Ayrıca büyük bölümü 3'üncü Ordu iaşe sınırları içinde bulunan Ermenilerin Rusya'nın desteğiyle isyan etmesi, bölgedeki üretimi sekteye uğrattığ1 gibi emniyeti ve asayişi de bozdu. Osmanlı Hükûmeti bölgedeki emniyeti sağlamak adına Ermenileri belli bölgelere göç ettirdi. İaşe ve ikmal kaynaklarının bir bölümünün bunlara hasredilmesi iaşe sorunun daha da derinleşmesine neden oldu. ${ }^{86}$

3'üncü Ordunun iaşe hususunda yaşadığı zorlukların temel nedenlerinden biri de menzil teşkilatında yaşanan aksaklıklardı. Ordunun ikmal hizmetlerinden sorumlu olan bu geri hizmet sisteminin zamanında idari yapısını tamamlayamaması özellikle de nakliye hususunda büyük sorunların yaşanmasına neden oldu. Ordu bölgesine ulaşan bir demir yolu hattının bulunmaması ve deniz yolunun kısa sürede Türklere kapanması nakliye hizmetlerinin yalnızca kara yoluyla yürütülmesi zorunluluğunu doğurdu. Ancak ordu bünyesinde motorlu araç sayısı oldukça sınırlı olduğundan nakliye faaliyetleri bütünüyle yük hayvanları vasıtasıyla gerçekleştirilmeye çalışıldı. Bunun için de çok fazla yük hayvanına ihtiyaç vardı. Ancak elde yeterli yük hayvanı bulunmadığı gibi hastalık ve bakımsızlık nedeniyle mevcut hayvanlardan da yeterince istifade edilemedi. İkmal hususunda yaşanan bu sorunlar nedeniyle ordu, gerilerden yeterince desteklenemedi. ${ }^{87}$

Bölgenin tam anlamıyla dağlık arazi karakterini taşıması, yollardaki altyapı sorunu, kış aylarının oldukça sert ve uzun sürmesi kısaca coğrafya ve mevsimden kaynaklanan zorluklar özellikle de ikmal faaliyetlerini olumsuz etkiliyordu. Kış mevsiminin sert ve yoğun kar yağışlı geçtiği yıllarda nakliye hizmetleri güçlükle yürütülürdü. Nitekim 1916 kış1 oldukça sert ve şiddetli geçtiğinden ikmal hizmetlerinde büyük aksaklıklar yaşandığından askerin günlük istihkakının ancak yarısı karşılanabildi. 1917 kışı ise bir önceki yıllara nazaran çok daha hafif geçtiğinden ordu nispeten daha iyi beslenebildi. ${ }^{88}$

Tüm bu olumsuzluklar neticesinde 3 'üncü Ordu iaşe hususunda büyük sorunlarla karşı karşıya kaldı. Ordunun beslenme hususunda yaşadığı bu

\footnotetext{
${ }^{86}$ BOA; DH. ŞFR, 54/50. Guze; s. 57. Sadık Erdaş; s. 688-690.

${ }^{87}$ BDH; Kls. H3, Dos. 3, Fih. 26. BDH; Kls. 3055, Dos. H2, Fih. 2-5a, 2-15. BDH; Kls. 1131, Dos. 39, Fih. 11-2, 14, 14-1. Sanders; s. 176, 210. Guze; s. 89. Kafkas Cephesi 3'üncü Ordu Harekât1; s. 223. Mehmed Emin; s. 35-36.

${ }^{88}$ Bölgenin coğrafi özelliklerinden ötürü nakliyatın belkemiğini oluşturan Ulukışla-Sivas-Erzurum hattında ulaşım çeşitli geçitler vasıtasıyla gerçekleştiriliyordu. Sivas-Hafik arasında bulunan Seyfebeli ve Suşehri-Şerefiye arasındaki Karabayır geçitleri kış mevsiminde yoğun kar aldıklarından bu dönemlerde sürekli kapanmakta ve ikmal hizmetleri zaman zaman aksamaktaydı. BOA; DH. İ. UM. EK., 5/2. Kafkas Cephesi 3'üncü Ordu Harekâtı; s. 16-17. Ericson; s. 175. Guze; s. 89. Vasfi Şensözen; s. 64.
} 
vahim tablo askerî harekâtı doğrudan etkileyerek harbin gidişatı üzerinde büyük tesir meydana getirdi. ${ }^{89}$

\section{Sonuç}

Osmanlı Devleti, Alman iaşe sistemini örnek alarak ülke topraklarını iaşe bölgelerine ayırdı. Buna göre her ordu, ihtiyaçlarını öncelikle kendilerine tahsis edilen bölgelerden karşılamak durumundaydı. Başlangıçta Erzurum, Trabzon, Van, Bitlis, Mamuretülaziz, Diyarbekir ve Musul vilayetlerini kapsayan oldukça geniş bir bölge 3'üncü Ordu iaşe bölgesi olarak belirlendi. Ancak 3'üncü Ordunun Ruslar karşısında tutunamayıp sürekli geri çekilmesi ile ordunun iaşe sınırları içinde yer alan bölgelerin büyük kısmı kaybedildi. İaşe bölgesinin büyük bölümünün elden çıkmasıyla ordunun ihtiyaçları merkezden gönderilen iaşe maddeleri ile tamamlanmaya çalışıldı. Ancak daha harbin başından itibaren deniz yolunun Türklere kapanması ve cepheye doğrudan ulaşan bir demir yolu şebekesinin bulunmaması, bölgedeki kara yolu ulaşımının ilkel vasıtalarla yapılıyor olması gibi nedenlerden ötürü ordu merkezden de yeterince desteklenemedi.

Ordunun her türlü lojistik ve bütünleme hizmetlerini yürüten 3'üncü Menzil Müfettişliğinin zamanında tertibini tamamlayamaması, menzil işleyişinde görülen aksaklıklar, ulaşım yolları ve nakliye araçlarındaki yetersizlikler, bölgenin dağlık yapısı ve elverişsiz iklim koşulları ikmal hizmetlerini sekteye uğrattı. Dolayısıyla daha harbin başından itibaren orduda büyük bir iaşe sorunu baş gösterdi. Osmanlı Devleti için çözümü imkânsız olan bu sorun, her geçen gün şiddetini daha da arttırdı. Bu durum askerler arasında hastalıkların yayılmasına zemin hazırladığı gibi firar gibi ordunun düzen ve disiplinini bozan fiillerin temel nedenlerinden biri oldu. Netice itibariyla yetersiz beslenme, ordunun mücadele gücünü, azim ve kararlılığını etkileyecek boyuta ulaşmış oldu.

\section{Kaynaklar}

Ahmet İzzet Paşa; Feryadım, Yay. haz. S. İ. Furkaç, C I, Nehir Yay. İstanbul, 1992.

ATAMAN, H.; Harp ve Esaret (Doğu Cephesi'nden Sibirya'ya), haz. Ferhat Ecer, Türkiye İş Bankası Kül. Yay., İstanbul, 2011.

Başkanlık Osmanlı Arşivi (BOA): Belge numaraları metin içinde verilmiştir.

ÇAKMAK, F.; Birinci Dünya Savaşı'nda Doğu Cephesi, Genelkurmay Basımevi, Ankara, 2005.

${ }^{89}$ Hafız Hakkı Paşa; s. 62.

Askerî Tarih Araştırmaları Dergisi (ATAD), Yıl 2021, Sayı 33:63-92 
ÇALIŞLAR, İzzettin; On Ylllık Savaşın Günlügü̈, Balkan, Birinci Dünya ve İstiklal Savaşları, haz. İsmet Görgülü-İzzeddin Çalışlar, Yap1 Kredi Yay., İstanbul, 1997.

ÇELOĞLU, Yavuz Selim; "Birinci Dünya Savaşı'nda Doğu Cephesi'nin Lojistik Organizasyonu: 3'üncü Menzil Müfettişliği”, Çanakkale Araştırmaları Türk Yıllığı, Yı1 17, S 29, Güz/2020, s. 7-33.

ÇELOĞLU, Yavuz Selim; Çanakkale Cephesi'nde 5. Ordunun İaşesi, Yayımlanmamış Yüksek Lisans Tezi, Frrat Üniversitesi Sosyal Bilimler Enstitüsü, Elâzığ, 2013.

ÇELOĞLU, Yavuz Selim; Çanakkale Cephesi'nde Askerî Nakliye Hizmetleri: 5. Ordu Menzil Teşkilatı, Yayımlanmamış Doktora Tezi, Fırat Üniversitesi Sosyal Bilimler Enstitüsü, Elâzı ̆̆, 2018.

DUMAN, Önder; "Birinci Dünya Savaşı Yıllarında Karadeniz'de Osmanlı Kayık Taşımacılığı”, Uluslararası Karadeniz Inceleme Dergisi, 2007, 1 (2), s. 137-147.

DURGUN, Bülent; Balkan Harbi'nde Osmanlı Ordusunun Ulaştırma Faaliyetleri 1912-1913, Türkiye İş Bankası Kültür Yayınları, İstanbul, 2018.

Düstur; "Askerî Tayınât ve Kanûn-1 Muvakkat”, Tertip II, C 6, s. 1286-1301.

Düstur; “Tekâlif-i Harbiye'nin Suret-i Tarhı Hakkında Kanun", Tertip II, C 6, s. 1011.

Düstur; "Tekâlif-i Harbiye'nin Suret-i Tarhına Mütedair 4 Ramazan 1332 tarihli Kanûn'a Müzeyyel Kanûnu Muvakkat”, Tertip II, C 8, s. 938.

ELDEM, V.; Harp ve Mütareke Ylllarında Osmanlı Imparatorluğu'nun Ekonomisi, TTK Yay., Ankara, 1994.

ELDEM, V.; Harp ve Mütareke Ylllarında Osmanlı Imparatorluğu'nun Ekonomisi, TTK Yay., Ankara, 1994.

ERDAŞ, Sadık; "Hatıralar Işığında Kafkas Cephesi'nde Yaşanan Temel Sorunlar ve Gözlemler", 100. Yll Münasebetiyle Birinci Dünya Savaşı 'nda Kafkas (Doğu) Cephesi Uluslararası Sempozyumu, Erzurum, 2427 Eylül 2014, s. 665-693.

ERICKSON, E. J.; Size Ölmeyi Emrediyorum! Birinci Dünya Savaşı'nda Osmanlı Ordusu, çev. Tanju Akad, 2. Baskı, Kitap Yayınevi, İstanbul, 2003.

ETİ, Ali Rıza; Bir Onbaşının Doğu Cephesi Günlüğü 1914-1915, haz. Gönül Eti, İş Bankası Kül. Yay., İstanbul, 2019. 
FERTAN, H. R.; Hasan Remzi Fertan'ın Harp Hatıraları (Çanakkale, Kafkas, Filistin Cepheleri ve Istiklal Harbi), haz. Lokman Erdemir, Bağc1lar Belediyesi Kül. Yay., İstanbul, 2016.

GENÇ, Mehmet; “İltizam”, İA, C 22, İstanbul, s. 154-158.

Genelkurmay Başkanlığı, Birinci Dünya Harbi Türk Harbi, Kafkas Cephesi 3'üncü Ordu Harekâtı; C II Kitap I, Genelkurmay Basımevi, Ankara, 1993.

Genelkurmay Başkanlığı, Türk Silahlı Kuvvetleri Tarihi Osmanlı Devri Birinci Dünya Harbi İdari Faaliyetler ve Lojistik X. Cilt; Genelkurmay Başkanlığı Yay., Ankara, 1995.

GUZE; Birinci Dünya Savaşı'nda Kafkas Cephesi'ndeki Muharebeler, Yay. haz. Alev Keskin, Genelkurmay Askerî Tarih ve Stratejik Etüt Başkanlığı Yay., Ankara, 2007.

Hafız Hakkı Paşa; Hafız Hakkı Paşa'nın Sarıkamış Günlüğü, Yay. haz. Murat Bardakçı, Türkiye İş Bankası Kül. Yay., İstanbul, 2020.

Harp Mecmuas1; Y11 1, S 24, İstanbul, 1 Kânunuevvel 1331.

İLKIN, S.-TEKELİ, İ; Osmanl Imparatorluğu'nun I. Dünya Savaşı'ndaki Ekonomik Düzenlemeler İçinde İaşe Nezareti ve Kara Kemal Bey'in Yeri, XII. Türk Tarih Kongresi, Ayrı Basım, Ankara, 2000.

İLTER, Aziz Samih; Birinci Dünya Savaşı'nda Kafkas Cephesi Hatıraları, Genelkurmay Basımevi, Ankara, 2007.

Luvve-i Umumiyeler Hakkında Talimat; Matbaa-i Askeriye, İstanbul, 1333

Menzil Hidemât-1 Nizamnamesi; Matbaa-i Askeriye, Süleymaniye, İstanbul, 1327.

MSB Arşiv ve Askerî Tarih Daire Başkanlığı Arşivi; Birinci Dünya Harbi Koleksiyonu: Belge numaraları metin içinde verilmiştir.

ORTAK, Şaban; "Sarıkamış Harekâtı Öncesi Kafkas Cephesi'ne Deniz Nakliyatı ve Yaşanan Deniz Savaşları", 100. Yllı Münasebetiyle I. Dünya Savaşı'nda Kafkas (Doğu) Cephesi Uluslararası Sempozyumu, C 1, Erzurum, 25-27 Eylül 2014, s. 283-308.

ÖĞÜN, Tuncay; Kafkas Cephesi’nin I. Dünya Savaşı'ndaki Lojistik Desteği, Dergâh Yay., İstanbul, 2015.

ÖZBAY, Kemal; Türk Asker Hekimliği Tarihi ve Asker Hastaneleri, C 1, Yörük Basımevi, İstanbul, 1976. 
ÖZGEN, Mehmet Sinan; Bolvadinli Mehmet Sinan Bey'in Harp Hatıralart, Yay. haz. S. Avşar, H. Babacan, M. Bayar, İstanbul, Haziran 2011.

SALIM, Tevfik; "Büyük Harp'te Kafkas Cephesi'ndeki Sihhi Vaziyete Dair Bir Tetkik", Askerî Mecmua, C VI, S 97, İstanbul, 1335, s. 487-504.

SANDERS, Liman von; Türkiye'de Beş Yll, çev. Eşref Bengi Özbilen, Türkiye İş Bankası Kül. Yay., İstanbul, 2011.

ŞENSÖZEN, Vasfi; I. Dünya Savaşı Yılları ve Kafkas Cephesi Anılart, Yay. haz. Saro Dadyan, Okyanus Yay., İstanbul, 2013.

TEKİR, Süleyman; "Birinci Dünya Savaşı'nda Doğu Anadolu ve Doğu Karadeniz Rus İşgali Bölgelerinden Yapılan Göçler”, Çağdaş Türkiye Tarihi Araştırmaları Dergisi, XVI/32, Bahar 2016, s. 43-65.

TOPRAK, Zafer; Itttihat-Terakki ve Cihan Harbi: Savaş Ekonomisi ve Türkiye'de Devletçilik 1914-1918, Homer Kitabevi, İstanbul, 2003. 